\title{
Energy and Nutrient Intake in the European Union
}

\author{
On the Basis of the National Data
}

Beside agricultural statistics, such as food balance sheets, or availability data at the household level, most European countries also accomplish assessments of nutrient and energy intake at an individual level.

In this chapter, intake data of the participating countries based on an individual level are presented by sex and age group. These data have to be interpreted cautiously as the participating countries used different assessment methods which make direct comparability difficult. Further the assessments were conducted in different years and the age classifications are in general not uniform. The presented data still give a good overview of the nutritional situation in European countries.

\section{Energy and Nutrient Intake in European Children}

Most of the participating countries had data about energy and nutrient intake in children. As Finland was the only country with available data for infants, these data were included here as well. The methods used for the assessment of dietary data in children are listed in table 6.

\section{Energy and Macronutrients}

Tables $7 \mathrm{a}$ and $7 \mathrm{~b}$ show that the average energy intake in children of the participating countries increased with increasing age. Further, the difference in energy intake between girls and boys became more considerable with increasing age. In Finland and Italy no separate intake data for boys and girls exist.

The relative share of protein in total energy intake was between 12 and $17 \%$ in girls and boys of the participating countries. In Germany this proportion seemed to be particularly low compared to other countries, with only $12 \% \mathrm{E}$ in all age groups (except for girls aged 7-9 years). Also in the UK it was very low with $12-13 \% \mathrm{E}$ in all age groups. In Spanish children the mean proportion of this macronutrient seemed to be relatively high with $17 \% \mathrm{E}$ in girls and boys of both age groups $(2-5$ and 6-13 years). Also in 13 months old Finnish children the average intake of protein was $17 \% \mathrm{E}$. There was hardly any difference between boys and girls of the same age group and country. Only in Austrian boys the proportion

Table 6. Methods and period of dietary assessment in children of European countries

\begin{tabular}{|c|c|c|c|}
\hline Country & Age group & Method & Year of survey \\
\hline \multirow[t]{2}{*}{ Austria } & $3-6$ years & 3-day-weighed record & 2001 \\
\hline & $7-14$ years & 7-day-weighed record & $2000-2001$ \\
\hline Belgium & $6-12$ years & 1-day-weighed record & 1989-1990 \\
\hline Denmark & $1-14$ years & $\begin{array}{l}\text { 7-day-record, personal } \\
\text { interview }\end{array}$ & 1995 \\
\hline \multirow[t]{3}{*}{ Finland } & 8 months & 3-day-record & 1999 \\
\hline & $\begin{array}{l}13 \text { months- } \\
4 \text { years }\end{array}$ & 3-day and 4-day-record & 1999 \\
\hline & $1-7$ years & 3-day-record & 1992 \\
\hline Germany & $4-14$ years & HBS & 1998 \\
\hline Greece & $2-14$ years & $\begin{array}{l}\text { 3-day-household } \\
\text { measured record }\end{array}$ & 1985-1987 \\
\hline \multirow[t]{2}{*}{ Hungary } & $12-13$ years & $3 \times 24$-hour-records & 1995 \\
\hline & 14-15 years & $3 \times 24$-hour-records & 1997 \\
\hline Italy & $1-14$ years & Not indicated & 1994-1996 \\
\hline Norway & $4-13$ years & 4-day-record & 2000 \\
\hline Portugal & 7-9 years & 24-hour-recall & $2000-2002$ \\
\hline Spain & $2-13$ years & 24-hour-recall & 1998-2000 \\
\hline \multirow[t]{2}{*}{ UK } & $1-14$ years & $\begin{array}{l}\text { 4-day-weighed record } \\
\text { (1-4 years) }\end{array}$ & $\begin{array}{l}1992-1993 \\
(1-4 \text { years })\end{array}$ \\
\hline & & $\begin{array}{l}\text { 7-day-weighed record } \\
\text { (4-14 years) }\end{array}$ & $\begin{array}{l}1997 \\
(4-14 \text { years })\end{array}$ \\
\hline
\end{tabular}


Table 7a. Intake of energy and macronutrients (mean \pm SD) in children of European countries (boys)

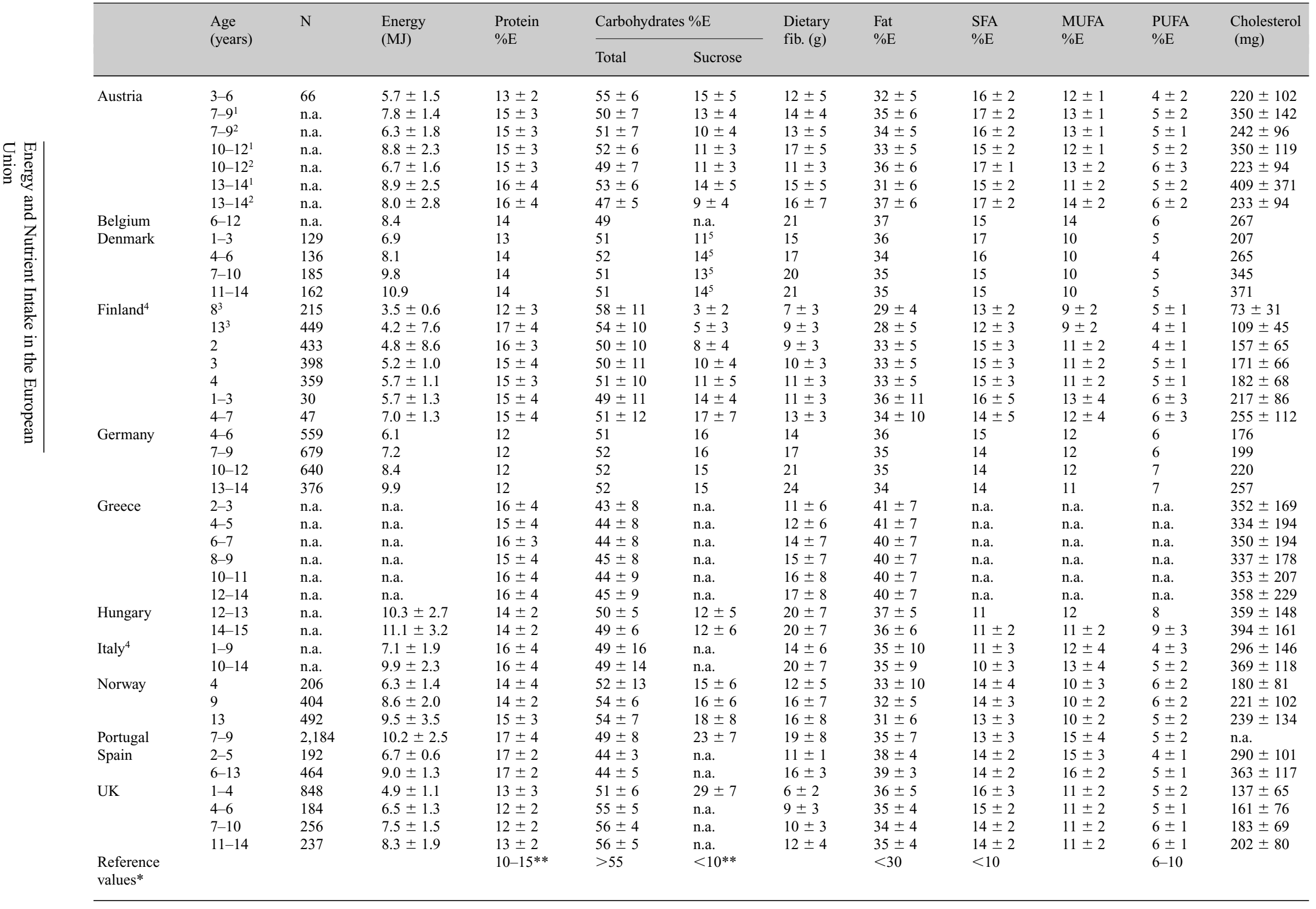

1 Eastern Austria, ${ }^{2}$ Western Austria, ${ }^{3}$ months, ${ }^{4}$ boys and girls, ${ }^{5}$ added sugar.

* Eurodiet, 2000; ** WHO (2003); n.a. = not available. 
Table 7b. Intake of energy and macronutrients (mean \pm SD) in children of European countries (girls)

\begin{tabular}{|c|c|c|c|c|c|c|c|c|c|c|c|c|c|}
\hline & & \multirow{2}{*}{$\begin{array}{l}\text { Age } \\
\text { (years) }\end{array}$} & \multirow[t]{2}{*}{$\mathrm{N}$} & \multirow{2}{*}{$\begin{array}{l}\text { Energy } \\
\text { (MJ) }\end{array}$} & \multirow{2}{*}{$\begin{array}{l}\text { Protein } \\
\% \mathrm{E}\end{array}$} & \multicolumn{2}{|c|}{ Carbohydrates \%E } & \multirow{2}{*}{$\begin{array}{l}\text { Dietary } \\
\text { fib. (g) }\end{array}$} & \multirow{2}{*}{$\begin{array}{l}\text { Fat } \\
\% \mathrm{E}\end{array}$} & \multirow{2}{*}{$\begin{array}{l}\text { SFA } \\
\% \mathrm{E}\end{array}$} & \multirow{2}{*}{$\begin{array}{l}\text { MUFA } \\
\% \mathrm{E}\end{array}$} & \multirow{2}{*}{$\begin{array}{l}\text { PUFA } \\
\% \mathrm{E}\end{array}$} & \multirow{2}{*}{$\begin{array}{l}\text { Cholesterol } \\
(\mathrm{mg})\end{array}$} \\
\hline & & & & & & Total & Sucrose & & & & & & \\
\hline & \multirow[t]{7}{*}{ Austria } & $3-6$ & 85 & $5.6 \pm 1.1$ & $13 \pm 3$ & $54 \pm 6$ & $15 \pm 5$ & $12 \pm 4$ & $33 \pm 5$ & $17 \pm 2$ & $12 \pm 1$ & $4 \pm 2$ & $206 \pm 89$ \\
\hline & & $7-9^{1}$ & n.a. & $7.2 \pm 1.2$ & $14 \pm 3$ & $50 \pm 6$ & $13 \pm 4$ & $14 \pm 3$ & $36 \pm 6$ & $17 \pm 2$ & $13 \pm 2$ & $6 \pm 2$ & $314 \pm 205$ \\
\hline & & $7-9^{2}$ & n.a. & $4.9 \pm 1.6$ & $14 \pm 2$ & $50 \pm 2$ & $11 \pm 5$ & $8 \pm 4$ & $36 \pm 5$ & $18 \pm 2$ & $13 \pm 1$ & $6 \pm 2$ & $212 \pm 115$ \\
\hline$\subseteq \underset{J}{\square}$ & & $10-12^{1}$ & n.a. & $7.4 \pm 2.4$ & $15 \pm 3$ & $54 \pm 7$ & $13 \pm 5$ & $16 \pm 6$ & $31 \pm 5$ & $15 \pm 2$ & $11 \pm 2$ & $5 \pm 2$ & $293 \pm 149$ \\
\hline हె. & & $10-12^{2}$ & n.a. & $6.7 \pm 1.5$ & $15 \pm 3$ & $50 \pm 7$ & $10 \pm 4$ & $13 \pm 5$ & $35 \pm 5$ & $16 \pm 2$ & $13 \pm 1$ & $6 \pm 2$ & $245 \pm 139$ \\
\hline 50 & & $13-14^{1}$ & n.a. & $7.5 \pm 2.3$ & $15 \pm 3$ & $51 \pm 6$ & $11 \pm 4$ & $15 \pm 5$ & $34 \pm 6$ & $17 \pm 2$ & $12 \pm 2$ & $5 \pm 2$ & $299 \pm 128$ \\
\hline 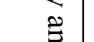 & & $13-14^{2}$ & n.a. & $6.7 \pm 2.5$ & $14 \pm 2$ & $52 \pm 6$ & $12 \pm 6$ & $13 \pm 6$ & $34 \pm 6$ & $17 \pm 3$ & $12 \pm 2$ & $5 \pm 3$ & $234 \pm 140$ \\
\hline 3 & \multirow{5}{*}{$\begin{array}{l}\text { Belgium } \\
\text { Denmark }\end{array}$} & $6-12$ & n.a. & 7.9 & 13 & 49 & n.a. & 19 & 38 & 15 & 14 & 7 & 245 \\
\hline & & $1-3$ & 149 & 6.4 & 14 & 50 & $11^{5}$ & 14 & 36 & 17 & 10 & 5 & 221 \\
\hline & & $4-6$ & 137 & 7.3 & 13 & 52 & $14^{5}$ & 15 & 34 & 16 & 10 & 4 & 234 \\
\hline$\cong$ & & $7-10$ & 191 & 8.8 & 14 & 49 & $13^{5}$ & 17 & 35 & 15 & 10 & 5 & 334 \\
\hline$\Xi$ & & $11-14$ & 172 & 8.7 & 15 & 51 & $13^{5}$ & 19 & 35 & 15 & 10 & 5 & 281 \\
\hline $\overrightarrow{ٍ ٍ ٍ ~}$ & \multirow[t]{7}{*}{ Finland $^{4}$} & $8^{3}$ & 215 & $3.5 \pm 0.6$ & $12 \pm 3$ & $58 \pm 11$ & $3 \pm 2$ & $7 \pm 3$ & $29 \pm 4$ & $13 \pm 2$ & $9 \pm 2$ & $5 \pm 1$ & $73 \pm 31$ \\
\hline 商 & & $13^{3}$ & 449 & $4.2 \pm 7.6$ & $17 \pm 4$ & $54 \pm 10$ & $5 \pm 3$ & $9 \pm 3$ & $28 \pm 5$ & $12 \pm 3$ & $9 \pm 2$ & $4 \pm 1$ & $109 \pm 45$ \\
\hline$\Xi \cdot$ & & 2 & 433 & $4.8 \pm 8.6$ & $16 \pm 3$ & $50 \pm 10$ & $8 \pm 4$ & $9 \pm 3$ & $33 \pm 5$ & $15 \pm 3$ & $11 \pm 2$ & $4 \pm 1$ & $157 \pm 65$ \\
\hline$\vec{\sigma}$ & & 3 & 398 & $5.2 \pm 1.0$ & $15 \pm 4$ & $50 \pm 11$ & $10 \pm 4$ & $10 \pm 3$ & $33 \pm 5$ & $15 \pm 3$ & $11 \pm 2$ & $5 \pm 1$ & $171 \pm 66$ \\
\hline$(\pi)$ & & 4 & 359 & $5.7 \pm 1.1$ & $15 \pm 3$ & $51 \pm 10$ & $11 \pm 5$ & $11 \pm 3$ & $33 \pm 5$ & $15 \pm 3$ & $11 \pm 2$ & $5 \pm 1$ & $182 \pm 68$ \\
\hline$\Xi$ & & $1-3$ & 30 & $5.7 \pm 1.3$ & $15 \pm 4$ & $49 \pm 11$ & $14 \pm 4$ & $11 \pm 3$ & $36 \pm 11$ & $16 \pm 5$ & $13 \pm 4$ & $6 \pm 3$ & $217 \pm 86$ \\
\hline$\frac{8}{8}$ & & $4-7$ & 47 & $7.0 \pm 1.3$ & $15 \pm 4$ & $51 \pm 12$ & $17 \pm 7$ & $13 \pm 3$ & $34 \pm 10$ & $14 \pm 5$ & $12 \pm 4$ & $6 \pm 3$ & $255 \pm 112$ \\
\hline & \multirow[t]{4}{*}{ Germany } & $4-6$ & 528 & 5.8 & 12 & 50 & 16 & 14 & 37 & 15 & 12 & 6 & 177 \\
\hline & & $7-9$ & 627 & 6.4 & 13 & 51 & 15 & 16 & 36 & 14 & 12 & 6 & 176 \\
\hline & & $10-12$ & 600 & 7.6 & 12 & 52 & 15 & 19 & 35 & 14 & 11 & 7 & 196 \\
\hline & & $13-14$ & 381 & 8.2 & 12 & 53 & 16 & 21 & 34 & 14 & 11 & 7 & 208 \\
\hline & \multirow[t]{6}{*}{ Greece } & $2-3$ & n.a. & n.a. & $16 \pm 4$ & $42 \pm 8$ & n.a. & $10 \pm 5$ & $42 \pm 7$ & n.a. & n.a. & n.a. & $354 \pm 203$ \\
\hline & & $4-5$ & n.a. & n.a. & $16 \pm 4$ & $43 \pm 9$ & n.a. & $12 \pm 7$ & $41 \pm 7$ & n.a. & n.a. & n.a. & $329 \pm 174$ \\
\hline & & $6-7$ & n.a. & n.a. & $15 \pm 3$ & $44 \pm 8$ & n.a. & $13 \pm 7$ & $40 \pm 6$ & n.a. & n.a. & n.a. & $318 \pm 167$ \\
\hline & & $8-9$ & n.a. & n.a. & $15 \pm 4$ & $44 \pm 9$ & n.a. & $13 \pm 6$ & $40 \pm 7$ & n.a. & n.a. & n.a. & $323 \pm 194$ \\
\hline & & $10-11$ & n.a. & n.a. & $16 \pm 4$ & $44 \pm 9$ & n.a. & $14 \pm 7$ & $41 \pm 7$ & n.a. & n.a. & n.a. & $329 \pm 196$ \\
\hline & & $12-14$ & n.a. & n.a. & $15 \pm 3$ & $45 \pm 9$ & n.a. & $15 \pm 8$ & $41 \pm 8$ & n.a. & n.a. & n.a. & $349 \pm 248$ \\
\hline & \multirow[t]{2}{*}{ Hungary } & $12-13$ & n.a. & $9.5 \pm 2.3$ & $13 \pm 2$ & $50 \pm 6$ & $12 \pm 5$ & $20 \pm 7$ & $37 \pm 5$ & 11 & 12 & 8 & $317 \pm 138$ \\
\hline & & $14-15$ & n.a. & $9.3 \pm 2.4$ & $14 \pm 2$ & $50 \pm 5$ & $13 \pm 6$ & $19 \pm 6$ & $36 \pm 5$ & $11 \pm 2$ & $11 \pm 2$ & $9 \pm 2$ & $320 \pm 118$ \\
\hline & \multirow{2}{*}{ Italy $^{4}$} & $1-9$ & n.a. & $7.1 \pm 1.9$ & $16 \pm 4$ & $49 \pm 16$ & n.a. & $14 \pm 6$ & $35 \pm 10$ & $11 \pm 3$ & $12 \pm 4$ & $4 \pm 3$ & $296 \pm 146$ \\
\hline & & $10-14$ & n.a. & $9.9 \pm 2.3$ & $16 \pm 4$ & $49 \pm 14$ & n.a. & $20 \pm 7$ & $35 \pm 9$ & $10 \pm 3$ & $13 \pm 4$ & $5 \pm 2$ & $369 \pm 118$ \\
\hline & \multirow[t]{3}{*}{ Norway } & 4 & 185 & $6.0 \pm 1.2$ & $14 \pm 3$ & $53 \pm 11$ & $15 \pm 7$ & $12 \pm 4$ & $33 \pm 9$ & $15 \pm 4$ & $10 \pm 3$ & $6 \pm 2$ & $168 \pm 65$ \\
\hline & & 9 & 411 & $7.7 \pm 2.0$ & $14 \pm 3$ & $55 \pm 6$ & $18 \pm 6$ & $14 \pm 6$ & $31 \pm 5$ & $14 \pm 3$ & $10 \pm 2$ & $6 \pm 2$ & $197 \pm 105$ \\
\hline & & 13 & 517 & $8.0 \pm 2.6$ & $14 \pm 3$ & $55 \pm 6$ & $19 \pm 7$ & $14 \pm 7$ & $31 \pm 5$ & $14 \pm 3$ & $10 \pm 2$ & $5 \pm 2$ & $196 \pm 105$ \\
\hline & Portugal & $7-9$ & 2,113 & $9.6 \pm 2.4$ & $17 \pm 4$ & $49 \pm 8$ & $22 \pm 7$ & $18 \pm 8$ & $35 \pm 7$ & $13 \pm 3$ & $15 \pm 4$ & $5 \pm 2$ & n.a. \\
\hline & Spain & $2-5$ & 175 & $6.3 \pm 0.7$ & $17 \pm 2$ & $45 \pm 3$ & n.a. & $10 \pm 3$ & $38 \pm 3$ & $14 \pm 3$ & $15 \pm 2$ & $4 \pm 1$ & $254 \pm 96$ \\
\hline & & $6-13$ & 448 & $7.9 \pm 1.0$ & $17 \pm 2$ & $43 \pm 3$ & n.a. & $14 \pm 2$ & $40 \pm 3$ & $14 \pm 2$ & $16 \pm 2$ & $5 \pm 1$ & $329 \pm 118$ \\
\hline & UK & $1-4$ & 827 & $4.7 \pm 1.1$ & $13 \pm 3$ & $51 \pm 6$ & $29 \pm 7$ & $6 \pm 2$ & $36 \pm 5$ & $16 \pm 3$ & $11 \pm 2$ & $5 \pm 2$ & $140 \pm 72$ \\
\hline & & $4-6$ & 172 & $5.8 \pm 1.2$ & $12 \pm 2$ & $55 \pm 5$ & n.a. & $8 \pm 3$ & $35 \pm 4$ & $15 \pm 2$ & $11 \pm 2$ & $5 \pm 1$ & $155 \pm 58$ \\
\hline & & $7-10$ & 225 & $6.7 \pm 1.6$ & $12 \pm 2$ & $55 \pm 5$ & n.a. & $10 \pm 3$ & $35 \pm 4$ & $14 \pm 2$ & $11 \pm 2$ & $6 \pm 1$ & $171 \pm 67$ \\
\hline & & $11-14$ & 238 & $7.0 \pm 1.6$ & $13 \pm 2$ & $55 \pm 5$ & n.a. & $10 \pm 3$ & $35 \pm 5$ & $14 \pm 2$ & $12 \pm 2$ & $6 \pm 2$ & $172 \pm 73$ \\
\hline & Reference values* & & & & $10-15^{* *}$ & $>55$ & $<10^{* *}$ & & $<30$ & $<10$ & & $6-10$ & \\
\hline
\end{tabular}

1 Eastern Austria, ${ }^{2}$ Western Austria, ${ }^{3}$ months, ${ }^{4}$ boys and girls, ${ }^{5}$ added sugar.

* Eurodiet, 2000;** WHO (2003); n.a. = not available. 
seemed on average to be slightly higher in boys than in girls.

In Spain and Greece the mean carbohydrate intake in children was, with $42-45 \% \mathrm{E}$, particularly low. In all other countries the proportion was on average at least $50 \% \mathrm{E}$ or only slightly below it. In Finnish infants (8 months) it was particularly high with $58 \% \mathrm{E}$ as well as in those aged 13 months. In the UK, children aged 4-14 years had a high proportion of carbohydrates in their daily diet with $55-56 \% \mathrm{E}$ in both boys and girls. Also in Norwegian girls $(55 \% \mathrm{E})$ and boys $(54 \% \mathrm{E})$ at the age of 9 and 13 years and in Austrian girls (54\%E) and boys (55\%E) aged 3-6 years the mean proportion of carbohydrates was relatively high. The share of sucrose in total energy intake should preferably be below 10\%. In Finnish children aged 8 and 13 months, 2 years and 3 years this upper level of the WHO (2003) was not exceeded. Children of all other countries and age groups had a mean sucrose intake which was higher than $10 \% \mathrm{E}$. In Norwegian and German children of all age groups but also in Austrian children of the first age group it was particularly high with an average proportion of $15 \% \mathrm{E}$ or more.

The mean intake of dietary fibre in children of the participating countries generally increased with increasing age. Apart from Finnish children aged 2 years or less and children living in the UK aged 1-6 years, it was between 10 and $20 \mathrm{~g} /$ day. Only German children of the last age group (13-14 years) had an average intake higher than $20 \mathrm{~g} /$ day.

Apart from Finnish infants at the age of 8 and 13 months, the mean proportion of fat in total energy intake was above $30 \%$. In Greek children the average fat intake was particularly high and was between 40 and $42 \% \mathrm{E}$. With $38-40 \%$ E it was very high in Spanish children as well, but also in Belgian children with $38 \% \mathrm{E}$ in girls and $37 \% \mathrm{E}$ in boys. The share of saturated fatty acids (SFA) in total energy intake should be below $10 \%$.

The lowest intake of SFA was found in Italian children with $10-11 \% \mathrm{E}$ and in Hungary with $11 \% \mathrm{E}$ in boys and girls aged $12-15$ years. Also in Finnish infants at the age of 8 and 13 months the intake was still low with $12-13 \%$ E. Children of other participating countries had a mean intake which was between 14 and $18 \% \mathrm{E}$ which was clearly above the upper level of the WHO (2003). There was hardly any difference between boys and girls. The proportion of monounsaturated fatty acids (MUFA) was on average between 10 and $13 \% \mathrm{E}$ in children of the participating countries. It was only slightly lower in
Finnish infants (8 and 13 months) with $9 \%$ E. The highest intake of MUFA was found in Spain with $15 \% \mathrm{E}$ in boys and girls at the age of $2-5$ years and $16 \% \mathrm{E}$ in those aged 6-13 years. In Belgian children the average intake of MUFA was $14 \% \mathrm{E}$.

The WHO recommends an intake of polyunsaturated fatty acid (PUFA) of at least $6 \% \mathrm{E}$. Based on this recommendation the average intake of PUFA was too low in Danish, Italian and Spanish children of all examined age groups, as well as Finnish, Austrian and Norwegian children of some age groups. The mean supply was very good in Hungarian children with $8-9 \% \mathrm{E}$ in girls and boys, but also in Germany it can be regarded as sufficient.

The mean intake of cholesterol was relatively high in children of some of the European countries. In Austrian children aged 7-14 years of Eastern Austria it was around $300 \mathrm{mg} /$ day in girls and between 350 and $410 \mathrm{mg} /$ day in boys. Also in Hungarian and Italian children, in Spanish boys (2-13 years) and girls (6-13 years), as well as in Danish girls (7-10 years) and boys (7-14 years) the mean cholesterol intake was high. A relatively low intake of cholesterol was observed in German and in Norwegian children.

\section{Vitamins}

Based on the population reference intakes of vitamin A indicated by the SCF (1993), the intake of this nutrient can on average be regarded as sufficient in children of the participating countries (tables $8 \mathrm{a}$ and $8 \mathrm{~b}$ ). The lowest vitamin A intake was found in Spanish children with $0.4-0.5 \mathrm{mg} \mathrm{RE} / \mathrm{day}$. The $\beta$-carotene intake in children was not assessed in all countries. Of those who had intake data of this nutrient, Denmark had the highest mean intake in both girls and boys. On average, there was no meaningful difference in $\beta$-carotene intake between boys and girls. Only in Germany it was higher in girls than in boys of the same age groups.

The average vitamin D intake in children of European countries was low. Apart from Italian children at the age of 10-14 years and 9 year old Norwegian boys, the average intake was below $3 \mu \mathrm{g} /$ day. As the requirement for vitamin $\mathrm{D}$ from food depends on the endogenously produced amount of this vitamin, the SCF (1993) does not give any exact recommendations for children older than 3 years but only a range of $0-10 \mu \mathrm{g} / \mathrm{day}$. In regard to a relatively low amount of sun exposure during winter months, and a generally low amount of sun irradiation in countries of Northern Europe, this low average intake in European children may not always be sufficient. For 
Table 8a. Vitamin intake (mean $\pm \mathrm{SD}$ ) in children of European countries (boys)

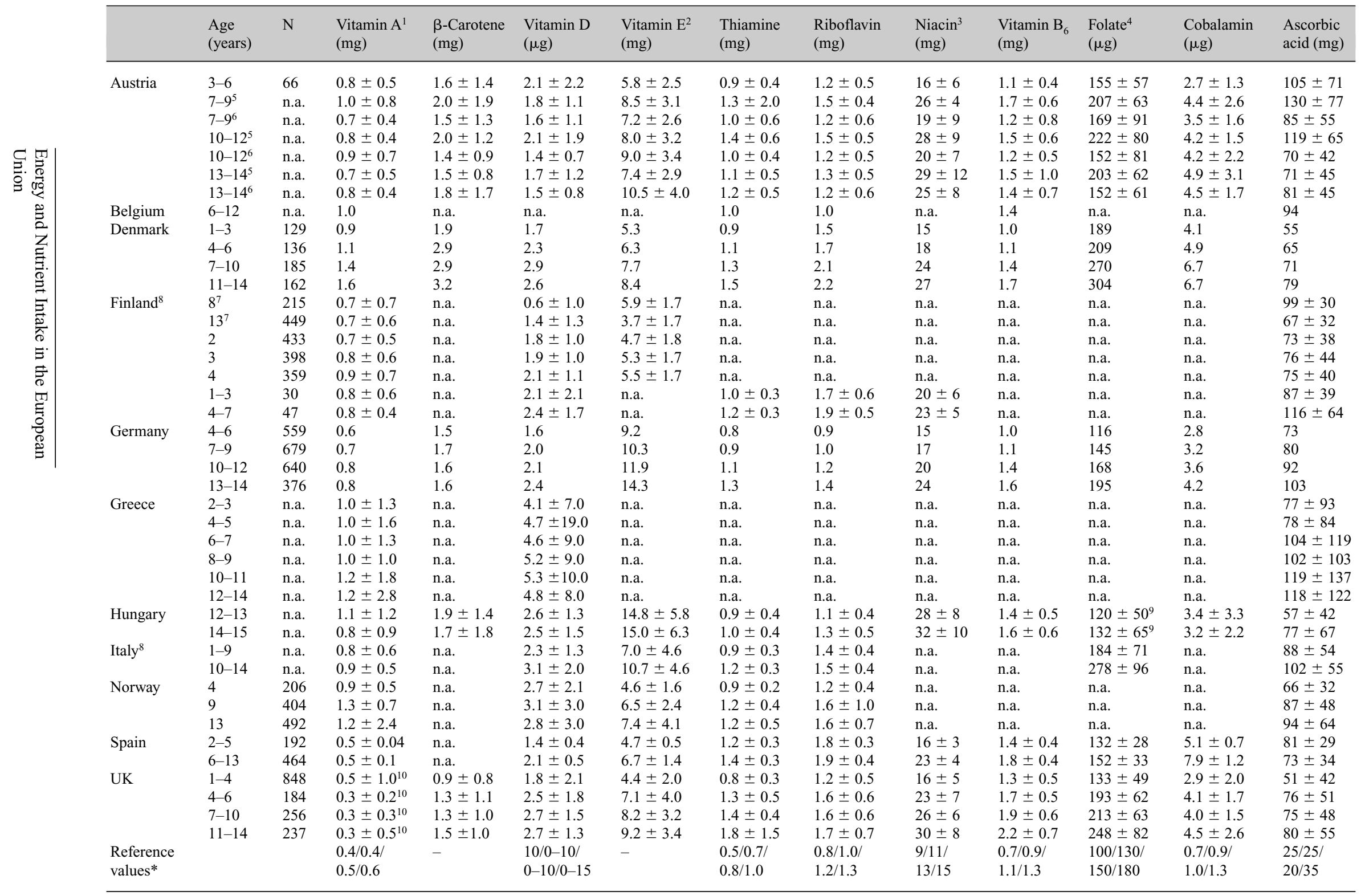

Retinol equivalent $(=1 \mathrm{mg}$ retinol $=6 \mathrm{mg}$ all-trans- $\beta$-carotene $=12 \mathrm{mg}$ other carotenoids $),{ }^{2}$ RRR- $\alpha$-Tocopherol equivalent $(=\mathrm{mg} \alpha$-tocopherol $+\mathrm{mg} \beta$-tocopherol $\times 0.5+\mathrm{mg}$ $\gamma$-tocopherol $\times 0.25+\mathrm{mg} \alpha$-tocotrienol $\times 0.33),{ }^{3} \quad$ Niacin equivalent $(=1 \mathrm{mg}$ niacin $=60 \mathrm{mg}$ tryptophan $),{ }^{4}$ Folate equivalent $(=1 \mu \mathrm{g}$ food folate $=0.5 \mu \mathrm{g}$ folic acid $(\mathrm{PGA})=0.6 \mu \mathrm{g}$ folic acid taken with meals), ${ }^{5}$ Eastern Austria, ${ }^{6}$ Western Austria, ${ }^{7}$ months, ${ }^{8}$ boys and girl, ${ }^{9}$ Folic acid $\left(=1 \mu \mathrm{g}\right.$ pteroylmonoglutamate $=1 \mu \mathrm{g}$ free folic acid $=2 \mu \mathrm{g}$ food folate), ${ }^{10}$ preformed-retinol.

* SCF, 1993; reference values refer to age groups $1-3$ years/4-6 years/7-10 years/11-14 years; $n$.a. $=$ not available. 
Table 8b. Vitamin intake (mean $\pm \mathrm{SD}$ ) in children of European countries (girls)

\begin{tabular}{|c|c|c|c|c|c|c|c|c|c|c|c|c|c|}
\hline & $\begin{array}{l}\text { Age } \\
\text { (years) }\end{array}$ & $\mathrm{N}$ & $\begin{array}{l}\text { Vitamin } \mathrm{A}^{1} \\
(\mathrm{mg})\end{array}$ & $\begin{array}{l}\beta \text {-Carotene } \\
(\mathrm{mg})\end{array}$ & $\begin{array}{l}\text { Vitamin D } \\
(\mu \mathrm{g})\end{array}$ & $\begin{array}{l}\text { Vitamin } E^{2} \\
(\mathrm{mg})\end{array}$ & $\begin{array}{l}\text { Thiamine } \\
(\mathrm{mg})\end{array}$ & $\begin{array}{l}\text { Riboflavin } \\
\text { (mg) }\end{array}$ & $\begin{array}{l}\text { Niacin }^{3} \\
\text { (mg) }\end{array}$ & $\begin{array}{l}\text { Vitamin } B_{6} \\
(\mathrm{mg})\end{array}$ & $\begin{array}{l}\text { Folate }^{4} \\
(\mu \mathrm{g})\end{array}$ & $\begin{array}{l}\text { Cobalamin } \\
(\mu \mathrm{g})\end{array}$ & $\begin{array}{l}\text { Ascorbic } \\
\text { acid (mg) }\end{array}$ \\
\hline \multirow[t]{7}{*}{ Austria } & $3-6$ & 85 & $0.7 \pm 0.5$ & $1.8 \pm 1.7$ & $1.9 \pm 2.1$ & $5.9 \pm 2.7$ & $0.9 \pm 0.3$ & $1.2 \pm 0.5$ & $16 \pm 5$ & $1.1 \pm 0.4$ & $172 \pm 118$ & $2.5 \pm 1.2$ & $95 \pm 60$ \\
\hline & $7-9^{5}$ & n.a. & $0.8 \pm 0.7$ & $1.8 \pm 1.7$ & $1.9 \pm 1.2$ & $8.0 \pm 3.0$ & $1.1 \pm 0.4$ & $1.3 \pm 0.4$ & $23 \pm 6$ & $1.5 \pm 0.5$ & $189 \pm 51$ & $4.1 \pm 3.1$ & $115 \pm 66$ \\
\hline & $7-9^{6}$ & n.a. & $0.7 \pm 0.5$ & $1.3 \pm 1.2$ & $1.3 \pm 0.8$ & $5.9 \pm 3.0$ & $0.8 \pm 0.4$ & $0.9 \pm 0.4$ & $14 \pm 6$ & $1.0 \pm 0.4$ & $132 \pm 68$ & $2.9 \pm 1.6$ & $63 \pm 33$ \\
\hline & $10-12^{5}$ & n.a. & $0.7 \pm 0.5$ & $1.9 \pm 1.1$ & $1.5 \pm 1.1$ & $7.1 \pm 2.9$ & $1.1 \pm 0.5$ & $1.3 \pm 0.5$ & $25 \pm 15$ & $1.6 \pm 2.6$ & $196 \pm 73$ & $3.8 \pm 4.5$ & $102 \pm 66$ \\
\hline & $10-12^{6}$ & n.a. & $0.7 \pm 0.3$ & $1.5 \pm 1.0$ & $1.4 \pm 1.0$ & $9.9 \pm 3.4$ & $1.1 \pm 0.5$ & $1.2 \pm 0.5$ & $20 \pm 7$ & $1.3 \pm 0.6$ & $169 \pm 86$ & $3.2 \pm 1.4$ & $77 \pm 35$ \\
\hline & $13-14^{5}$ & n.a. & $0.8 \pm 0.6$ & $2.1 \pm 2.0$ & $1.5 \pm 0.8$ & $6.5 \pm 2.3$ & $1.1 \pm 0.5$ & $1.2 \pm 0.5$ & $24 \pm 10$ & $1.3 \pm 0.6$ & $183 \pm 60$ & $3.9 \pm 2.5$ & $99 \pm 73$ \\
\hline & $13-14^{6}$ & n.a. & $0.6 \pm 0.3$ & $1.4 \pm 1.2$ & $1.3 \pm 0.8$ & $9.2 \pm 5.9$ & $0.9 \pm 0.3$ & $1.0 \pm 0.3$ & $18 \pm 7$ & $1.1 \pm 0.5$ & $151 \pm 61$ & $2.8 \pm 1.0$ & $85 \pm 50$ \\
\hline Belgium & $6-12$ & n.a. & 0.8 & n.a. & n.a. & n.a. & 0.9 & 0.8 & $? ? ?$ & 1.3 & n.a. & n.a. & 99 \\
\hline \multirow[t]{4}{*}{ Denmark } & $1-3$ & 149 & 0.9 & 2.4 & 1.8 & 5.1 & 0.9 & 1.6 & 16 & 1.0 & 183 & 4.7 & 64 \\
\hline & $4-6$ & 137 & 1.0 & 2.6 & 1.7 & 6.1 & 0.9 & 1.5 & 16 & 1.0 & 189 & 4.1 & 61 \\
\hline & $7-10$ & 191 & 1.3 & 4.1 & 2.4 & 7.1 & 1.1 & 1.8 & 22 & 1.3 & 229 & 5.2 & 66 \\
\hline & $11-14$ & 172 & 1.2 & 2.9 & 2.3 & 6.3 & 1.1 & 1.7 & 23 & 1.4 & 238 & 5.1 & 72 \\
\hline \multirow[t]{7}{*}{ Finland $^{8}$} & $8^{7}$ & 215 & $0.7 \pm 0.7$ & n.a. & $0.6 \pm 1.0$ & $5.9 \pm 1.7$ & n.a. & n.a. & n.a. & n.a. & n.a. & n.a. & $99 \pm 30$ \\
\hline & $13^{7}$ & 449 & $0.7 \pm 0.6$ & n.a. & $1.4 \pm 1.3$ & $3.7 \pm 1.7$ & n.a. & n.a. & n.a. & n.a. & n.a. & n.a. & $67 \pm 32$ \\
\hline & 2 & 433 & $0.7 \pm 0.5$ & n.a. & $1.8 \pm 1.0$ & $4.7 \pm 1.8$ & n.a. & n.a. & n.a. & n.a. & n.a. & n.a. & $73 \pm 38$ \\
\hline & 3 & 398 & $0.8 \pm 0.6$ & n.a. & $1.9 \pm 1.0$ & $5.3 \pm 1.7$ & n.a. & n.a. & n.a. & n.a. & n.a. & n.a. & $76 \pm 44$ \\
\hline & 4 & 359 & $0.9 \pm 0.7$ & n.a. & $2.1 \pm 1.1$ & $5.5 \pm 1.7$ & n.a. & n.a. & n.a. & n.a. & n.a. & n.a. & $75 \pm 40$ \\
\hline & $1-3$ & 30 & $0.8 \pm 0.6$ & n.a. & $2.1 \pm 2.1$ & n.a. & $1.0 \pm 0.3$ & $1.7 \pm 0.6$ & $20 \pm 6$ & n.a. & n.a. & n.a. & $87 \pm 39$ \\
\hline & $4-7$ & 47 & $0.8 \pm 0.4$ & n.a. & $2.4 \pm 1.7$ & n.a. & $1.2 \pm 0.3$ & $1.9 \pm 0.5$ & $23 \pm 5$ & n.a. & n.a. & n.a. & $116 \pm 64$ \\
\hline \multirow{4}{*}{ Germany } & $4-6$ & 528 & 0.8 & 2.2 & 1.9 & 8.8 & 0.8 & 0.9 & 14 & 0.9 & 129 & 2.8 & 86 \\
\hline & $7-9$ & 627 & 0.8 & 2.2 & 1.5 & 9.2 & 0.9 & 1.0 & 16 & 1.1 & 134 & 2.9 & 85 \\
\hline & $10-12$ & 600 & 0.9 & 2.1 & 1.6 & 11.2 & 1.0 & 1.1 & 18 & 1.3 & 155 & 3.2 & 85 \\
\hline & $13-14$ & 381 & 0.9 & 2.0 & 1.7 & 12.4 & 1.0 & 1.2 & 19 & 1.3 & 174 & 3.3 & 90 \\
\hline \multirow[t]{6}{*}{ Greece } & $2-3$ & n.a. & $1.0 \pm 2.0$ & n.a. & $3.6 \pm 6.0$ & n.a. & n.a. & n.a. & n.a. & n.a. & n.a. & n.a. & $67 \pm 76$ \\
\hline & $4-5$ & n.a. & $0.9 \pm 1.2$ & n.a. & $4.4 \pm 7.0$ & n.a. & n.a. & n.a. & n.a. & n.a. & n.a. & n.a. & $84 \pm 80$ \\
\hline & $6-7$ & n.a. & $0.8 \pm 1.4$ & n.a. & $3.8 \pm 6.0$ & n.a. & n.a. & n.a. & n.a. & n.a. & n.a. & n.a. & $93 \pm 94$ \\
\hline & $8-9$ & n.a. & $1.0 \pm 1.6$ & n.a. & $5.9 \pm 23.0$ & n.a. & n.a. & n.a. & n.a. & n.a. & n.a. & n.a. & $101 \pm 113$ \\
\hline & $10-11$ & n.a. & $1.0 \pm 1.5$ & n.a. & $4.3 \pm 8.0$ & n.a. & n.a. & n.a. & n.a. & n.a. & n.a. & n.a. & $108 \pm 119$ \\
\hline & $12-14$ & n.a. & $0.9 \pm 1.1$ & n.a. & $6.2 \pm 11.0$ & n.a. & n.a. & n.a. & n.a. & n.a. & n.a. & n.a. & $118 \pm 135$ \\
\hline \multirow[t]{2}{*}{ Hungary } & $12-13$ & n.a. & $0.9 \pm 0.9$ & $1.8 \pm 1.3$ & $2.2 \pm 1.3$ & $13.3 \pm 5.7$ & $0.8 \pm 0.3$ & $1.0 \pm 0.4$ & $26 \pm 8$ & $1.4 \pm 0.5$ & $109 \pm 42^{9}$ & $2.8 \pm 2.5$ & $61 \pm 43$ \\
\hline & $14-15$ & n.a. & $0.8 \pm 0.6$ & $1.7 \pm 1.6$ & $2.3 \pm 1.4$ & $13.0 \pm 5.0$ & $0.8 \pm 0.3$ & $1.1 \pm 0.4$ & $26 \pm 8$ & $1.4 \pm 0.5$ & $110 \pm 50^{9}$ & $2.6 \pm 1.9$ & $72 \pm 50$ \\
\hline \multirow[t]{2}{*}{ Italy $^{8}$} & $1-9$ & n.a. & $0.8 \pm 0.6$ & n.a. & $2.3 \pm 1.3$ & $7.0 \pm 4.6$ & $0.9 \pm 0.3$ & $1.4 \pm 0.4$ & n.a. & $1.6 \pm 0.5$ & $184 \pm 71$ & n.a. & $88 \pm 54$ \\
\hline & $10-14$ & n.a. & $0.9 \pm 0.5$ & n.a. & $3.1 \pm 2.0$ & $10.7 \pm 4.6$ & $1.2 \pm 0.3$ & $1.5 \pm 0.4$ & n.a. & $2.1 \pm 0.6$ & $278 \pm 96$ & n.a. & $102 \pm 55$ \\
\hline \multirow[t]{3}{*}{ Norway } & 4 & 185 & $1.0 \pm 1.0$ & n.a. & $2.4 \pm 1.5$ & $4.4 \pm 1.3$ & $0.8 \pm 0.2$ & $1.2 \pm 0.3$ & n.a. & n.a. & n.a. & n.a. & $68 \pm 30$ \\
\hline & 9 & 411 & $1.1 \pm 1.5$ & n.a. & $2.6 \pm 2.1$ & $5.7 \pm 2.0$ & $1.0 \pm 0.3$ & $1.3 \pm 0.4$ & n.a. & n.a. & n.a. & n.a. & $81 \pm 42$ \\
\hline & 13 & 517 & $1.0 \pm 1.2$ & n.a. & $2.4 \pm 2.5$ & $6.4 \pm 3.4$ & $1.0 \pm 0.4$ & $1.3 \pm 0.5$ & n.a. & n.a. & n.a. & n.a. & $85 \pm 52$ \\
\hline \multirow[t]{2}{*}{ Spain } & $2-5$ & 175 & $0.4 \pm 0.2$ & n.a. & $1.2 \pm 0.6$ & $4.6 \pm 1.6$ & $1.0 \pm 0.2$ & $1.7 \pm 0.5$ & $15 \pm 3$ & $1.3 \pm 0.2$ & $109 \pm 24$ & $5.5 \pm 0.7$ & $72 \pm 32$ \\
\hline & $6-13$ & 448 & $0.5 \pm 0.1$ & n.a. & $1.7 \pm 0.5$ & $6.4 \pm 2.2$ & $1.2 \pm 0.2$ & $1.6 \pm 0.2$ & $20 \pm 3$ & $1.5 \pm 0.3$ & $137 \pm 22$ & $6.4 \pm 0.9$ & $70 \pm 24$ \\
\hline \multirow[t]{4}{*}{ UK } & $1-4$ & 827 & $0.4 \pm 0.6^{10}$ & $0.8 \pm 0.7$ & $2.0 \pm 2.3$ & $4.4 \pm 2.0$ & $0.8 \pm 0.3$ & $1.2 \pm 0.5$ & $16 \pm 5$ & $1.2 \pm 0.5$ & $130 \pm 48$ & $2.8 \pm 1.6$ & $53 \pm 43$ \\
\hline & $4-6$ & 172 & $0.3 \pm 0.2^{10}$ & $1.2 \pm 0.7$ & $2.2 \pm 1.3$ & $6.6 \pm 2.7$ & $1.2 \pm 0.5$ & $1.4 \pm 0.5$ & $21 \pm 6$ & $1.6 \pm 0.5$ & $170 \pm 56$ & $3.6 \pm 1.5$ & $70 \pm 36$ \\
\hline & $7-10$ & 225 & $0.3 \pm 0.3^{10}$ & $1.3 \pm 0.8$ & $2.3 \pm 1.4$ & $7.7 \pm 3.0$ & $1.3 \pm 0.4$ & $1.4 \pm 0.5$ & $24 \pm 6$ & $1.8 \pm 0.7$ & $192 \pm 57$ & $3.5 \pm 1.5$ & $82 \pm 60$ \\
\hline & $11-14$ & 238 & $0.3 \pm 0.4^{10}$ & $1.3 \pm 1.0$ & $2.3 \pm 1.3$ & $8.3 \pm 3.2$ & $1.4 \pm 0.9$ & $1.4 \pm 0.6$ & $25 \pm 6$ & $1.9 \pm 0.7$ & $212 \pm 85$ & $3.4 \pm 1.7$ & $77 \pm 57$ \\
\hline Reference & & & $0.4 / 0.4 /$ & - & $10 / 0-10 /$ & - & $0.5 / 0.7 /$ & $0.8 / 1.0 /$ & $9 / 11 /$ & $0.7 / 0.9 /$ & $100 / 130 /$ & $0.7 / 0.9 /$ & $25 / 25 /$ \\
\hline values* & & & $0.5 / 0.6$ & & $0-10 / 0-15$ & & $0.8 / 0.9$ & $1.2 / 1.2$ & $13 / 14$ & $1.1 / 1.1$ & $150 / 180$ & $1.0 / 1.3$ & $20 / 35$ \\
\hline
\end{tabular}

1 Retinol equivalent $(=1 \mathrm{mg}$ retinol $=6 \mathrm{mg}$ all-trans- $\beta$-carotene $=12 \mathrm{mg}$ other carotenoids $),{ }^{2} \quad \mathrm{RRR}-\alpha$-Tocopherol equivalent $\quad(=\mathrm{mg} \quad \alpha$-tocopherol $+\mathrm{mg} \quad \beta$-tocopherol $\times 0.5+\mathrm{mg}$ $\gamma$-tocopherol $\times 0.25+\mathrm{mg} \alpha$-tocotrienol $\times 0.33),{ }^{3}$ Niacin equivalent $(=1 \mathrm{mg}$ niacin $=60 \mathrm{mg}$ tryptophan $),{ }^{4} \quad$ Folate equivalent $(=1 \mu \mathrm{g}$ food folate $=0.5 \mu \mathrm{g}$ folic acid $(\mathrm{PGA})=0.6 \mu \mathrm{g}$ folic acid taken with meals), ${ }^{5}$ Eastern Austria, ${ }^{6}$ Western Austria, ${ }^{7}$ months, ${ }^{8}$ boys and girls, ${ }^{9}$ Folic acid $(=1 \mu \mathrm{g}$ pteroylmonoglutamate $=1 \mu \mathrm{g}$ free folic acid $=2 \mu \mathrm{g}$ food folate $),{ }^{10}$ preformed-retinol; * SCF, 1993; reference values refer to age groups $1-3$ years/4-6 years/7-10 years/11-14 years; n.a. $=$ not available. 
children at the age of 1-3 years the SCF (1993) indicates a population reference intake of $10 \mu \mathrm{g}$ /day. In Denmark as well as in Finland, where children of this age group were examined, the average intake was far below this recommendation.

The mean vitamin $\mathrm{E}$ intake increased with increasing age. There was no noticeable difference between girls and boys or between the participating European countries. The SCF (1993) does not give any absolute guideline but only recommends that the intake of vitamin $\mathrm{E}$ should refer to the intake of PUFA (mg tocopherol equivalent $=0.4 \times \mathrm{g}$ PUFA).

In most children of the participating countries the mean intake of thiamine as well as of riboflavin seemed to be sufficient. The mean thiamine intake was below the recommendations of the SCF (1993) in Hungarian boys and girls only. In the male group the mean riboflavin intake was too low in Hungarian boys aged 12-13 years. In Hungarian, German and Western Austrian girls some age groups had an intake which was below the recommended level. The supply of niacin was on average clearly above the recommended level of the SCF (1993) and can thus be regarded as sufficient in children of the participating countries. Also the mean vitamin $B_{6}$ intakes approximately corresponded to the guidelines or were above them.

The mean folate intake in children was not satisfying in some of the countries. Compared to the population reference intakes of the SCF (1993), the average intake was too low in Austrian boys and girls of Western Austria, as well as in German and Spanish children. The mean intake of cobalamin as well as of ascorbic acid was above the recommendations of the SCF (1993) in boys and girls of all age groups.

\section{Minerals}

In Hungary and Italy the mean estimated sodium intake was already considerable in children of all age groups. In Hungarian boys and girls aged $12-15$ years it was between 5 and $5.4 \mathrm{~g} /$ day, in Italian 10-14 year olds it was $5 \mathrm{~g} /$ day as well (see tables $9 \mathrm{a}$ and $9 \mathrm{~b}$ ). These average intakes were already far above the upper level of the acceptable range of intake indicated for adults by the SCF (1993). An insufficient intake of potassium was found in Austrian and German boys and girls aged 7-14 years, in Hungarian children of both age groups, in Italian boys and girls at 10-14 years of age and in boys and girls of the UK aged 11-14 years. In the participating countries younger children had on average a more sufficient calcium supply than children of higher age groups. The mean intake was too low in Austrian and German children at the age of 10-14 years, in Hungarian children aged 12-15 years, as well as in UK, Italian and Norwegian children of the last age group. The mean intake of calcium was particularly high in Danish and Finnish children. On average, the supply of magnesium was slightly better in boys than it was in girls. An insufficient intake was observed in girls (7-14 years) and boys (10-14 years) of Western Austria, in Italian children aged 10-14 years, in girls and boys of the UK aged 7-14 years, and in Danish girls of the last age group (11-14 years). In children of all other age groups and countries the mean intake was above the guidelines. The supply of iron in European boys can on average be regarded as sufficient. Girls at fertile age seemed to have an insufficient intake of this nutrient. The mean iodine intake through food was too low in Austrian, Danish and German children. In Finnish children the mean iodine intake was very high and considerably exceeded the guidelines of the SCF (1993). All other countries did not assess the iodine intake in children.

\section{Energy and Nutrient Intake in European Adolescents}

Only half of the participating countries had available intake data of adolescents (see table 10). The data of these countries is not older than 10 years, which is a good basis for comparing the data. However, as different assessment methods were used in adolescents as well, the comparability between these countries is limited. The following methods were used for the assessment of energy and nutrient intake in this population group.

\section{Energy and Macronutrients}

The average intake of energy was as expected higher in male than in female adolescents (table 11). The share of protein in total energy intake was within the recommended range of the WHO (2003) in most of the participating countries. Only in Spanish adolescents and in Austrian male adolescents the upper level was exceeded. The proportion of carbohydrates in total energy intake should - according to Eurodiet (2000) - be at least 55\%. The highest proportion was found in Norwegian adolescents with $54-55 \%$. Also in the UK it was relatively high with an average of $53 \% \mathrm{E}$ (excl. alcohol). Adolescents of all other countries had clearly lower intakes of 
Table 9a. Mineral intake (mean \pm SD) in children of European countries (boys)

\begin{tabular}{|c|c|c|c|c|c|c|c|c|c|c|c|c|c|}
\hline & $\begin{array}{l}\text { Age } \\
\text { (years) }\end{array}$ & $\mathrm{N}$ & $\begin{array}{l}\text { Sodium } \\
(\mathrm{g})\end{array}$ & $\begin{array}{l}\text { Potassium } \\
(\mathrm{g})\end{array}$ & $\begin{array}{l}\text { Calcium } \\
(\mathrm{mg})\end{array}$ & $\begin{array}{l}\text { Phosphorous } \\
\text { (mg) }\end{array}$ & $\begin{array}{l}\text { Magnesium } \\
(\mathrm{mg})\end{array}$ & $\begin{array}{l}\text { Iron } \\
(\mathrm{mg})\end{array}$ & $\begin{array}{l}\text { Zinc } \\
(\mathrm{mg})\end{array}$ & $\begin{array}{l}\text { Iodine } \\
(\mu \mathrm{g})\end{array}$ & $\begin{array}{l}\text { Copper } \\
(\mathrm{mg})\end{array}$ & $\begin{array}{l}\text { Manganese } \\
(\mathrm{mg})\end{array}$ & $\begin{array}{l}\text { Selenium } \\
(\mu \mathrm{g})\end{array}$ \\
\hline \multirow[t]{7}{*}{ Austria } & $3-6$ & 66 & n.a. & $1.6 \pm 0.5$ & $646 \pm 302$ & n.a. & $200 \pm 73$ & $8.6 \pm 2.8$ & $6.5 \pm 2.1$ & $67 \pm 24$ & n.a. & n.a. & n.a. \\
\hline & $7-9^{1}$ & n.a. & n.a. & $2.1 \pm 0.5$ & $742 \pm 253$ & n.a. & $243 \pm 55$ & $11.5 \pm 2.7$ & $8.1 \pm 1.6$ & $102 \pm 39$ & n.a. & n.a. & n.a. \\
\hline & $7-9^{2}$ & n.a. & n.a. & $1.7 \pm 0.7$ & $718 \pm 384$ & n.a. & $241 \pm 94$ & $10.0 \pm 4.2$ & $7.7 \pm 2.8$ & $90 \pm 55$ & n.a. & n.a. & n.a. \\
\hline & $10-12^{1}$ & n.a. & n.a. & $2.3 \pm 0.6$ & $819 \pm 308$ & n.a. & $292 \pm 82$ & $12.0 \pm 3.6$ & $10.5 \pm 3$ & $96 \pm 41$ & n.a. & n.a. & n.a. \\
\hline & $10-12^{2}$ & n.a. & n.a. & $1.6 \pm 0.5$ & $611 \pm 240$ & n.a. & $192 \pm 56$ & $8.9 \pm 2.6$ & $7.6 \pm 2.7$ & $85 \pm 33$ & n.a. & n.a. & n.a. \\
\hline & $13-14^{1}$ & n.a. & n.a. & $2.1 \pm 0.8$ & $733 \pm 296$ & n.a. & $297 \pm 125$ & $12.6 \pm 3.7$ & $11.1 \pm 3.8$ & $100 \pm 50$ & n.a. & n.a. & n.a. \\
\hline & $13-14^{2}$ & n.a. & n.a. & $2.0 \pm 0.7$ & $632 \pm 290$ & n.a. & $240 \pm 103$ & $11.3 \pm 4.8$ & $10.1 \pm 3.6$ & $99 \pm 27$ & n.a. & n.a. & n.a. \\
\hline Belgium & $6-12$ & n.a. & 2.0 & 3.0 & 935 & 1,384 & n.a. & 10.4 & n.a. & n.a. & n.a. & n.a. & n.a. \\
\hline \multirow[t]{4}{*}{ Denmark } & $1-3$ & 129 & 2.2 & 2.2 & 910 & 1,143 & 228 & 6.7 & 7.5 & 58 & n.a. & n.a. & 24 \\
\hline & $4-6$ & 136 & 2.6 & 2.4 & 1,053 & 1,345 & 252 & 7.9 & 9.1 & 69 & n.a. & n.a. & 30 \\
\hline & $7-10$ & 185 & 3.3 & 2.8 & 1,224 & 1,612 & 288 & 9.9 & 11.5 & 84 & n.a. & n.a. & 39 \\
\hline & $11-14$ & 162 & 3.4 & 3.3 & 1,286 & 1,704 & 324 & 11.1 & 12.7 & 82 & n.a. & n.a. & 42 \\
\hline \multirow[t]{7}{*}{ Finland ${ }^{4}$} & $8^{3}$ & 215 & $0.7 \pm 0.3$ & n.a. & $425 \pm 107$ & n.a. & n.a. & $7.5 \pm 1.7$ & $4.1 \pm 1.3$ & n.a. & n.a. & n.a. & n.a. \\
\hline & $13^{3}$ & 449 & $1.6 \pm 0.5$ & n.a. & $807 \pm 240$ & n.a. & n.a. & $6.4 \pm 1.8$ & $6.2 \pm 1.7$ & n.a. & n.a. & n.a. & n.a. \\
\hline & 2 & 433 & $1.8 \pm 0.5$ & n.a. & $833 \pm 238$ & n.a. & n.a. & $7.0 \pm 2.2$ & $6.6 \pm 1.6$ & n.a. & n.a. & n.a. & n.a. \\
\hline & 3 & 398 & $2.0 \pm 0.5$ & n.a. & $845 \pm 247$ & n.a. & n.a. & $7.8 \pm 2.5$ & $7.0 \pm 1.6$ & n.a. & n.a. & n.a. & n.a. \\
\hline & 4 & 359 & $2.1 \pm 0.5$ & n.a. & $905 \pm 240$ & n.a. & n.a. & $8.8 \pm 3.1$ & $7.6 \pm 1.7$ & n.a. & n.a. & n.a. & n.a. \\
\hline & $1-3$ & 30 & n.a. & $2.4 \pm 0.7$ & $828 \pm 273$ & $1,047 \pm 279$ & $199 \pm 48$ & $8.4 \pm 3.2$ & $7.6 \pm 1.9$ & $250 \pm 95$ & n.a. & n.a. & n.a. \\
\hline & $4-7$ & 47 & n.a. & $2.7 \pm 0.6$ & $973 \pm 323$ & $1,225 \pm 319$ & $237 \pm 51$ & $10.2 \pm 3.1$ & $8.9 \pm 2.1$ & $299 \pm 133$ & n.a. & n.a. & n.a. \\
\hline \multirow[t]{4}{*}{ Germany } & $4-6$ & 559 & 1.2 & 1.7 & 554 & 797 & 206 & 7.7 & 6.4 & 48 & 1.1 & 2.6 & n.a. \\
\hline & $7-9$ & 679 & 1.6 & 1.9 & 639 & 939 & 244 & 9.2 & 7.5 & 56 & 1.4 & 3.3 & n.a. \\
\hline & $10-12$ & 640 & 2.0 & 2.3 & 726 & 1,088 & 291 & 11.1 & 8.7 & 68 & 1.7 & 3.9 & n.a. \\
\hline & $13-14$ & 376 & 2.4 & 2.7 & 835 & 1,252 & 338 & 12.9 & 10.1 & 86 & 1.9 & 4.5 & n.a. \\
\hline \multirow[t]{6}{*}{ Greece } & $2-3$ & n.a. & n.a. & n.a. & $824 \pm 307$ & n.a. & n.a. & $7.7 \pm 4.7$ & n.a. & n.a. & n.a. & n.a. & n.a. \\
\hline & $4-5$ & n.a. & n.a. & n.a. & $823 \pm 301$ & n.a. & n.a. & $8.6 \pm 4.7$ & n.a. & n.a. & n.a. & n.a. & n.a. \\
\hline & $6-7$ & n.a. & n.a. & n.a. & $899 \pm 335$ & n.a. & n.a. & $9.6 \pm 3.9$ & n.a. & n.a. & n.a. & n.a. & n.a. \\
\hline & $8-9$ & n.a. & n.a. & n.a. & $938 \pm 362$ & n.a. & n.a. & $10.2 \pm 4.6$ & n.a. & n.a. & n.a. & n.a. & n.a. \\
\hline & $10-11$ & n.a. & n.a. & n.a. & $963 \pm 402$ & n.a. & n.a. & $11.0 \pm 5.1$ & n.a. & n.a. & n.a. & n.a. & n.a. \\
\hline & $12-14$ & n.a. & n.a. & n.a. & $960 \pm 403$ & n.a. & n.a. & $11.9 \pm 6.1$ & n.a. & n.a. & n.a. & n.a. & n.a. \\
\hline \multirow[t]{2}{*}{ Hungary } & $12-13$ & n.a. & $5.9 \pm 1.7$ & $2.4 \pm 0.8$ & $612 \pm 264$ & n.a. & $321 \pm 97$ & $9.7 \pm 3.0$ & $7.7 \pm 2.5$ & n.a. & $1.5 \pm 1.6$ & n.a. & n.a. \\
\hline & $14-15$ & n.a. & $6.3 \pm 1.8$ & $2.6 \pm 0.8$ & $777 \pm 365$ & n.a. & $365 \pm 127$ & $10.3 \pm 3.1$ & $9.0 \pm 2.9$ & n.a. & $1.4 \pm 1.2$ & n.a. & n.a. \\
\hline \multirow[t]{2}{*}{ Italy $^{4}$} & $1-9$ & n.a. & $3.3 \pm 1.5$ & $2.3 \pm 0.7$ & $797 \pm 220$ & $1,101 \pm 281$ & $163 \pm 45$ & $8.9 \pm 3.2$ & $8.7 \pm 2.8$ & n.a. & $0.9 \pm 0.4$ & n.a. & $30.4 \pm 13.3$ \\
\hline & $10-14$ & n.a. & $5.0 \pm 1.8$ & $3.0 \pm 0.9$ & $862 \pm 283$ & $1,348 \pm 363$ & $222 \pm 62$ & $12.5 \pm 4.4$ & $12.3 \pm 3.4$ & n.a. & $1.4 \pm 0.5$ & n.a. & $41.6 \pm 16.2$ \\
\hline \multirow[t]{3}{*}{ Norway } & 4 & 206 & n.a. & n.a. & $684 \pm 215$ & n.a. & n.a. & $6.8 \pm 2.2$ & n.a. & n.a. & n.a. & n.a. & n.a. \\
\hline & 9 & 404 & n.a. & n.a. & $914 \pm 339$ & n.a. & n.a. & $9.3 \pm 3.0$ & n.a. & n.a. & n.a. & n.a. & n.a. \\
\hline & 13 & 492 & n.a. & n.a. & $933 \pm 497$ & n.a. & n.a. & $10.2 \pm 4.3$ & n.a. & n.a. & n.a. & n.a. & n.a. \\
\hline Portugal & $7-9$ & 2,184 & n.a. & n.a. & $1,104 \pm 426$ & n.a. & n.a. & n.a. & n.a. & n.a. & n.a. & n.a. & n.a. \\
\hline \multirow[t]{2}{*}{ Spain } & $2-5$ & 192 & $1.6 \pm 0.2$ & $2.4 \pm 0.3$ & $897 \pm 67$ & $1,201 \pm 151$ & $227 \pm 27$ & 10.3 & n.a. & n.a. & n.a. & n.a. & n.a. \\
\hline & $6-13$ & 464 & $2.5 \pm 0.6$ & $2.8 \pm 0.4$ & $983 \pm 164$ & $1,453 \pm 198$ & $283 \pm 46$ & $14.0 \pm 2.0$ & n.a. & n.a. & n.a. & n.a. & n.a. \\
\hline \multirow[t]{4}{*}{ UK } & $1-4$ & 848 & $1.5 \pm 0.5$ & $1.5 \pm 0.4$ & $651 \pm 255$ & $757 \pm 223$ & $140 \pm 38$ & $5.7 \pm 2.3$ & $4.5 \pm 1.4$ & n.a. & $0.5 \pm 0.2$ & n.a. & n.a. \\
\hline & $4-6$ & 184 & $2.0 \pm 0.5$ & $2.0 \pm 0.5$ & $723 \pm 260$ & $933 \pm 256$ & $175 \pm 46$ & $8.3 \pm 2.6$ & $5.6 \pm 1.8$ & n.a. & $0.7 \pm 0.4$ & n.a. & n.a. \\
\hline & $7-10$ & 256 & $2.4 \pm 0.6$ & $2.1 \pm 0.5$ & $745 \pm 231$ & $1,014 \pm 244$ & $194 \pm 47$ & $9.7 \pm 2.7$ & $6.1 \pm 1.6$ & n.a. & $0.8 \pm 0.2$ & n.a. & n.a. \\
\hline & $11-14$ & 237 & $2.7 \pm 0.7$ & $2.4 \pm 0.6$ & $803 \pm 285$ & $1,140 \pm 294$ & $220 \pm 61$ & $10.9 \pm 3.2$ & $7.2 \pm 2.1$ & n.a. & $0.9 \pm 0.4$ & n.a. & n.a. \\
\hline \multirow[t]{2}{*}{ Reference values* } & & & & $0.8 / 1.1 /$ & $400 / 450 /$ & $300 / 350 /$ & $85 / 120 /$ & $4 / 4 / 6 / 10$ & $4 / 6 / 7 / 9$ & 70/90/ & $0.4 / 0.6 /$ & $1-10$ & $10 / 15 /$ \\
\hline & & & & $2.0 / 3.1$ & $550 / 1,000$ & $450 / 775$ & $200 / 280$ & & & $100 / 120$ & $0.7 / 0.8$ & & $25 / 35$ \\
\hline
\end{tabular}

1 Eastern Austria, ${ }^{2}$ Western Austria, ${ }^{3}$ months, ${ }^{4}$ boys and girls.

* SCF, 1993; reference values refer to age groups 1-3 years/4-6 years/7-10 years/11-14 years; n.a. $=$ not available. 
Table 9b. Mineral intake (mean $\pm \mathrm{SD}$ ) in children of European countries (girls)

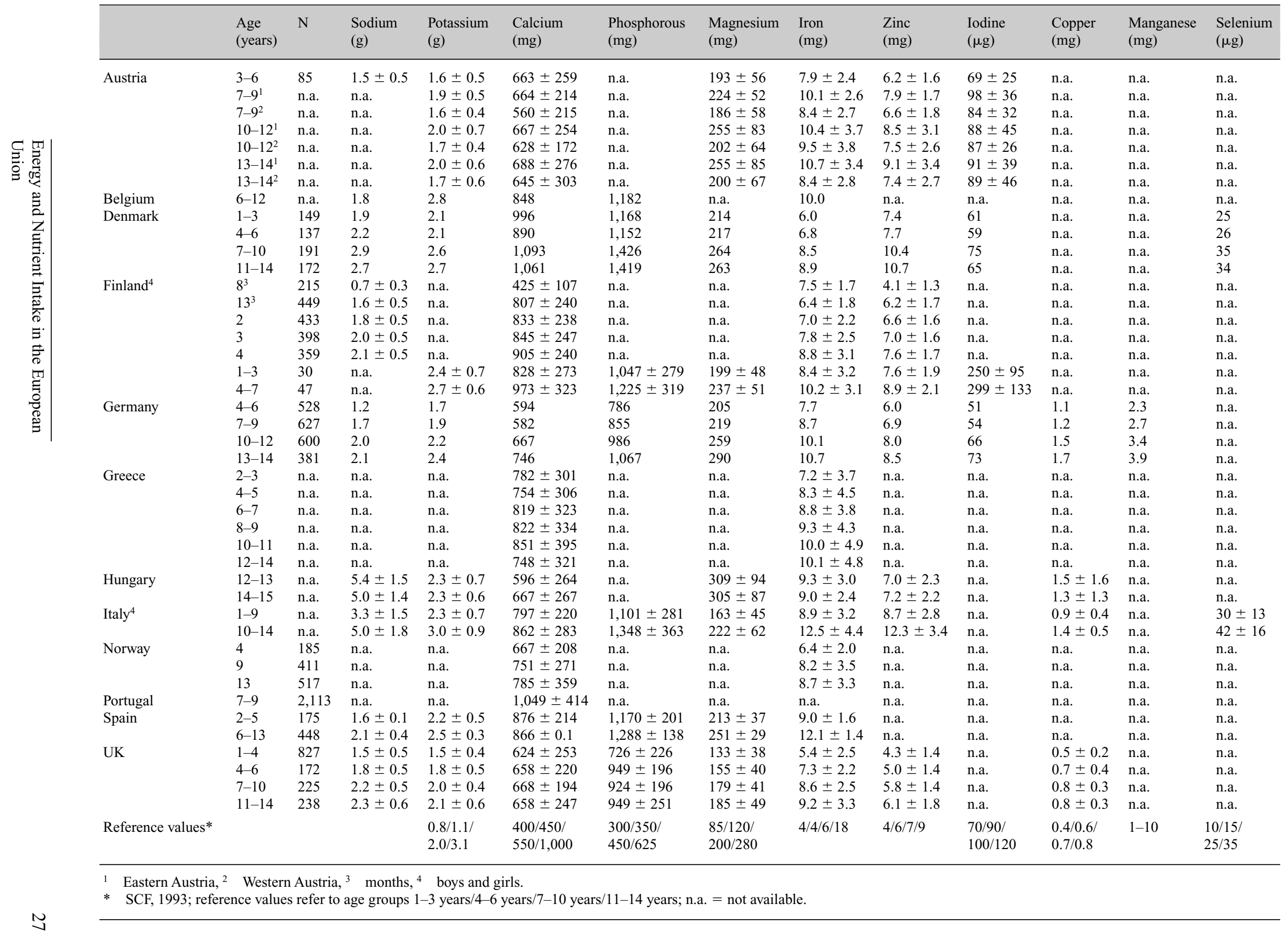


Table 10. Method and period of dietary assessment in adolescents of European countries

\begin{tabular}{llll}
\hline Country & Age group & Method & Year of survey \\
\hline Austria & $\begin{array}{c}\text { 15-18 years } \\
\text { (apprentices) }\end{array}$ & 3-day-weighed record & 2001 \\
Belgium & 13-18 years & 3-day-record, FFQ & 1998 \\
Denmark & 15-18 years & 7-day-record, personal interview & 1995 \\
Germany & 15-18 years & HBS & 1998 \\
Italy & 17 years & FFQ & 2003 \\
Norway & 16-19 years & FFQ & 1997 \\
Spain & 14-24 years & 24-hour-recall & $1998-2000$ \\
UK & 15-18 years & 7-day-weighed record & 1997 \\
\hline
\end{tabular}

carbohydrates. The lowest mean intake of carbohydrates was found in Spanish adolescents with only $42 \% \mathrm{E}$ (excl. alcohol). The average proportion of sucrose in total energy intake was above the level proposed by the WHO (2003) in all countries with data from adolescents. Sugar-sweetened beverages make a considerable contribution to total sucrose intake, not only in adolescents. A study carried out in young and middle-aged American women showed that a higher consumption of sugarsweetened beverages was associated with a greater magnitude of weight gain and an increased risk for development of type 2 diabetes [Schulze et al., 2004]. The lowest proportion was found in female adolescents of Norway and Denmark, the highest in Austrian female adolescents.

Beside a high proportion of carbohydrates and a low share of sucrose, adolescents in Norway and Germany had the highest intake of dietary fibre. In Austrian and Spanish adolescents, both male and female, as well as in Belgian and Danish female adolescents the mean intake of dietary fibre was clearly below $20 \mathrm{~g}$ /day.

The upper level of fat intake of Eurodiet $(30 \% \mathrm{E})$ was on average exceeded by adolescents of nearly all countries. Only Norwegian female adolescents were with $29 \%$ E below this upper level. Norwegian and Austrian male adolescents had a mean intake which was only slightly above the upper level. The highest proportion of fat in total energy intake was found in Spain (40 \% E, excl. alcohol) and Italy (39-40\%E), but also in Belgium, Denmark, the UK and Germany, as well as in Austrian female adolescents the proportion of fat was high. Beside this high fat intake, the proportion of SFA in the diet of adolescents was high as well. The lowest proportion was found in Spanish and UK adolescents (13\%E excl. alcohol) and in Norwegian female adolescents with only $12 \% \mathrm{E}$. In all other countries it was between 14 and $16 \% \mathrm{E}$. The upper level of Eurodiet
(2000) was exceeded by male and female adolescents of all countries. The mean proportion of MUFA in total energy intake was particularly high in Spanish adolescents. The highest proportion of PUFA was found in German adolescents with $7 \% \mathrm{E}$ in both males and females. The mean intake of cholesterol was generally higher in male than in female adolescents. In Denmark, both male and female adolescents exceeded on average the upper intake level ( $300 \mathrm{mg} /$ day) as proposed by the WHO (2003), in Austria and Norway the intake was only too high in the male group.

The proportion of alcohol in total energy intake was on average between 1 and $2 \%$ in adolescents of the participating countries. Only in Austrian male adolescents it was higher with $4 \% \mathrm{E}$.

\section{Vitamins}

Apart from Spain, the vitamin A intake can on average be regarded as sufficient in these European adolescents. Table 12 shows that Spanish adolescents had a mean intake of $0.5 \mathrm{mg} \mathrm{RE} /$ day, which was below the population reference intake of the SCF (1993). The $\beta$-carotene intake was only assessed in Austrian, Danish, UK and German adolescents. German and Austrian male adolescents, as well as UK male and female adolescents had the lowest average intakes of $\beta$-carotene with only $1.6 \mathrm{mg} /$ day. The highest average intake was found in Danish female adolescents. The mean vitamin D intake was particularly low in Austrian male and female adolescents and in Spanish female adolescents with less than $2 \mu \mathrm{g} /$ day. The highest average intakes were observed in Norwegian adolescents with $5.4 \mu \mathrm{g} /$ day in the male and $3.4 \mu \mathrm{g} /$ day in the female group.

The mean riboflavin intake was below the recommended level in Austrian and German male adolescents. In female adolescents of these countries the average 
Table 11. Intake of energy and macronutrients (mean \pm SD) in adolescents of European countries (male and female)

\begin{tabular}{|c|c|c|c|c|c|c|c|c|c|c|c|c|c|c|}
\hline & & \multirow{2}{*}{$\begin{array}{l}\text { Age } \\
\text { (years) }\end{array}$} & \multirow[t]{2}{*}{$\mathrm{N}$} & \multirow[t]{2}{*}{ Energy (MJ) } & \multirow{2}{*}{$\begin{array}{l}\text { Protein } \\
\% \mathrm{E}\end{array}$} & \multicolumn{2}{|c|}{ Carbohydrates \%E } & \multirow{2}{*}{$\begin{array}{l}\text { Dietary } \\
\text { fib. (g) }\end{array}$} & \multirow{2}{*}{$\begin{array}{l}\text { Fat } \\
\% \mathrm{E}\end{array}$} & \multirow{2}{*}{$\begin{array}{l}\text { SFA } \\
\% \mathrm{E}\end{array}$} & \multirow{2}{*}{$\begin{array}{l}\text { MUFA } \\
\% \mathrm{E}\end{array}$} & \multirow{2}{*}{$\begin{array}{l}\text { PUFA } \\
\% \mathrm{E}\end{array}$} & \multirow{2}{*}{$\begin{array}{l}\text { Cholesterol } \\
(\mathrm{mg})\end{array}$} & \multirow{2}{*}{$\begin{array}{l}\text { Alcohol } \\
\% \mathrm{E}\end{array}$} \\
\hline & & & & & & Total & Sucrose & & & & & & & \\
\hline \multirow{19}{*}{ 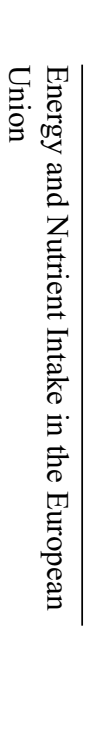 } & Male & & & & & & & & & & & & & \\
\hline & Austria & $15-18$ & 46 & $11.0 \pm 2.7$ & $16 \pm 3$ & $49 \pm 6$ & $16 \pm 6$ & $14 \pm 5$ & $31 \pm 6$ & $15 \pm 2$ & $11 \pm 2$ & $5 \pm 2$ & $367 \pm 131$ & $4 \pm 6$ \\
\hline & Belgium & $13-18$ & n.a. & $11.1 \pm 2.2$ & $14 \pm 2$ & $49 \pm 5$ & n.a. & $20 \pm 6$ & $36 \pm 5$ & $15 \pm 2$ & $14 \pm 2$ & $6 \pm 2$ & $265 \pm 72$ & $1 \pm 2$ \\
\hline & Denmark & $15-18$ & 68 & 11.9 & 14 & 49 & $13^{4}$ & 21 & 35 & 15 & 10 & 5 & 313 & 2 \\
\hline & Germany & $15-18$ & 796 & 10.5 & 13 & 51 & 15 & 24 & 35 & 14 & 12 & 7 & 288 & n.a. \\
\hline & Italy*** & 17 & 125 & $11.3 \pm 2.7$ & $15 \pm 4$ & $48 \pm 15$ & $14 \pm 6$ & $17 \pm 6$ & $39 \pm 10$ & $12 \pm 4$ & n.a. & n.a. & $334 \pm 111$ & $0.8 \pm 1.3$ \\
\hline & Norway & $16-19$ & n.a. & 13.9 & 14 & 54 & 16 & 26 & 31 & 14 & 11 & 5 & 362 & 1 \\
\hline & Spain & $14-24$ & 692 & $10.5 \pm 1.5$ & $18 \pm 2^{1}$ & $42 \pm 5^{1}$ & n.a. & $19 \pm 4$ & $40 \pm 5^{1}$ & $13 \pm 2^{1}$ & $17 \pm 2^{1}$ & $5 \pm 1^{1}$ & $479 \pm 160$ & $2 \pm 8$ \\
\hline & UK & $15-18$ & 179 & $9.6 \pm 2.4$ & $13 \pm 2^{2}$ & $53 \pm 6^{2}$ & n.a. & $13 \pm 5^{3}$ & $35 \pm 5^{2}$ & $13 \pm 2^{2}$ & $12 \pm 2^{2}$ & $6 \pm 1^{2}$ & $246 \pm 96$ & n.a. \\
\hline & Female & & & & & & & & & & & & & \\
\hline & Austria & $15-18$ & 56 & $8.6 \pm 1.7$ & $15 \pm 3$ & $51 \pm 7$ & $18 \pm 6$ & $15 \pm 5$ & $34 \pm 6$ & $16 \pm 3$ & $12 \pm 1$ & $6 \pm 2$ & $262 \pm 93$ & $1 \pm 2$ \\
\hline & Belgium & $13-18$ & n.a. & $8.2 \pm 1.9$ & $15 \pm 3$ & $49 \pm 5$ & n.a. & $16 \pm 5$ & $35 \pm 5$ & $14 \pm 2$ & $13 \pm 3$ & $6 \pm 1$ & $206 \pm 66$ & $1 \pm 1$ \\
\hline & Denmark & $15-18$ & 84 & 10.0 & 14 & 50 & $13^{4}$ & 19 & 34 & 15 & 10 & 4 & 333 & 2 \\
\hline & Germany & $15-18$ & 772 & 8.8 & 12 & 52 & 16 & 22 & 34 & 14 & 12 & 7 & 237 & n.a. \\
\hline & Italy*** & 17 & 108 & $8.6 \pm 2.4$ & $15 \pm 4$ & $48 \pm 14$ & $15 \pm 6$ & $14 \pm 5$ & $40 \pm 12$ & $13 \pm 4$ & n.a. & n.a. & $266 \pm 98$ & $0.3 \pm 0.3$ \\
\hline & Norway & $16-19$ & n.a. & 9.1 & 15 & 55 & 12 & 21 & 29 & 12 & 10 & 5 & 228 & 1 \\
\hline & Spain & $14-24$ & 884 & $8.1 \pm 1.1$ & $17 \pm 2^{1}$ & $42 \pm 6^{1}$ & n.a. & $15 \pm 3$ & $40 \pm 4^{1}$ & $13 \pm 2^{1}$ & $16 \pm 2^{1}$ & $5 \pm 1^{1}$ & $370 \pm 38$ & $1 \pm 6$ \\
\hline & UK & $15-18$ & 210 & $6.9 \pm 1.8$ & $13 \pm 2^{2}$ & $53 \pm 6^{2}$ & n.a. & $11 \pm 3^{3}$ & $35 \pm 5^{2}$ & $13 \pm 2^{2}$ & $11 \pm 2^{2}$ & $6 \pm 2$ & $181 \pm 79$ & n.a. \\
\hline & Reference values* & & & & $10-15^{* *}$ & $>55$ & $<10^{* *}$ & $>25$ & $<30$ & $<10$ & & $6-10$ & $<300 * *$ & \\
\hline
\end{tabular}

1 Excl. alcohol, ${ }^{2}$ \% of total food energy (excl. alcohol), ${ }^{3}$ Non-starchy polysaccharides, ${ }^{4}$ added sugar.

* Eurodiet, 2000; ** WHO; *** Rome, 2003; n.a. = not available. 
Table 12. Intake of vitamins and minerals (mean \pm SD) in adolescents of European countries (male and female)

\begin{tabular}{|c|c|c|c|c|c|c|c|c|c|c|c|c|c|c|}
\hline & & $\begin{array}{l}\text { Age } \\
\text { (years) }\end{array}$ & $\mathrm{N}$ & $\begin{array}{l}\text { Vitamin } A^{1} \\
(\mathrm{mg})\end{array}$ & $\begin{array}{l}\beta \text {-Caro- } \\
\text { tene }(\mathrm{mg})\end{array}$ & $\begin{array}{l}\text { Vitamin D } \\
(\mu g)\end{array}$ & $\begin{array}{l}\text { Vitamin } E^{2} \\
(\mathrm{mg})\end{array}$ & $\begin{array}{l}\text { Thiamine } \\
(\mathrm{mg})\end{array}$ & $\begin{array}{l}\text { Riboflavin } \\
(\mathrm{mg})\end{array}$ & $\operatorname{Niacin}^{3}$ (mg) & $\begin{array}{l}\text { Vitamin } B_{6} \\
(\mathrm{mg})\end{array}$ & $\begin{array}{l}\text { Folate }^{4} \\
(\mu g)\end{array}$ & $\begin{array}{l}\text { Cobalamin } \\
(\mu g)\end{array}$ & $\begin{array}{l}\text { Ascorbic acid } \\
(\mathrm{mg})\end{array}$ \\
\hline \multirow{16}{*}{ 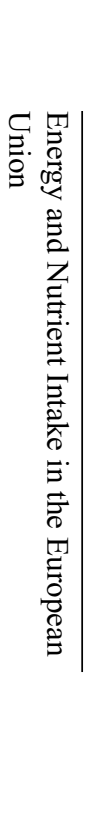 } & Male & & & & & & & & & & & & & \\
\hline & Austria & $15-18$ & 46 & $0.9 \pm 0.5$ & $1.6 \pm 1.7$ & $1.3 \pm 0.7$ & $9.9 \pm 4.3$ & $1.4 \pm 0.4$ & $1.4 \pm 0.5$ & $38 \pm 16$ & $2.0 \pm 1.0$ & $175 \pm 61$ & $5.2 \pm 1.9$ & $88 \pm 56$ \\
\hline & Denmark & $15-18$ & 68 & 1.4 & 2.1 & 3.0 & 9.1 & 1.5 & 2.3 & 30 & 1.7 & 295 & 7.1 & 65 \\
\hline & Germany & $15-18$ & 796 & 1.0 & 1.6 & 2.7 & 15.5 & 1.4 & 1.5 & 26 & 1.6 & 199 & 4.9 & 98 \\
\hline & Norway & $16-19$ & n.a. & 1.6 & n.a. & 5.4 & n.a. & 1.9 & 2.4 & 20 & n.a. & n.a. & n.a. & 129 \\
\hline & Spain & $14-24$ & 692 & $0.5 \pm 0.1$ & n.a. & $2.3 \pm 0.5$ & $8.2 \pm 1.6$ & $1.6 \pm 0.2$ & $1.9 \pm 0.3$ & $27 \pm 2$ & $1.9 \pm 0.2$ & $180 \pm 44$ & $9.1 \pm 1.4$ & $79 \pm 33$ \\
\hline & UK & $15-18$ & 179 & $0.4 \pm 0.3^{5}$ & $1.6 \pm 1.3$ & $3.3 \pm 1.8$ & $10.4 \pm 4.4$ & $2.0 \pm 0.8$ & $2.0 \pm 0.9$ & $37 \pm 11$ & $2.7 \pm 1.1$ & $312 \pm 127$ & $5.1 \pm 2.1$ & $89 \pm 69$ \\
\hline & $\begin{array}{l}\text { Reference } \\
\text { values* }\end{array}$ & & & 0.7 & - & $0-15$ & - & 1.1 & 1.6 & 18 & 1.5 & $200 / 400^{* *}$ & 1.4 & 40 \\
\hline & Female & & & & & & & & & & & & & \\
\hline & Austria & $15-18$ & 56 & $0.9 \pm 0.5$ & $2.1 \pm 2.2$ & $1.5 \pm 1.0$ & $10.9 \pm 4.6$ & $1.1 \pm 0.4$ & $1.3 \pm 0.5$ & $25 \pm 6$ & $1.6 \pm 0.9$ & $164 \pm 62$ & $3.5 \pm 1.4$ & $109 \pm 80$ \\
\hline & Denmark & $15-18$ & 84 & 1.3 & 3.6 & 2.7 & 7.4 & 1.2 & 1.8 & 25 & 1.5 & 266 & 5.5 & 79 \\
\hline & Germany & $15-18$ & 772 & 0.9 & 2.4 & 2.3 & 13.0 & 1.2 & 1.3 & 22 & 1.4 & 190 & 3.5 & 106 \\
\hline & Norway & $16-19$ & n.a. & 1.3 & n.a. & 3.4 & n.a. & 1.3 & 1.7 & 15 & n.a. & n.a. & n.a. & 119 \\
\hline & Spain & $14-24$ & 884 & $0.5 \pm 0.1$ & n.a. & $1.7 \pm 0.5$ & $6.8 \pm 1.6$ & $1.3 \pm 0.2$ & $1.6 \pm 0.2$ & $22 \pm 3$ & $1.6 \pm 0.3$ & $161 \pm 29$ & $7 \pm 1$ & $81 \pm 33$ \\
\hline & UK & $15-18$ & 210 & $0.3 \pm 0.3^{5}$ & $1.6 \pm 1.8$ & $2.2 \pm 1.3$ & $8.7 \pm 7.3$ & $1.4 \pm 0.9$ & $1.3 \pm 0.7$ & $26 \pm 8$ & $2.0 \pm 2.0$ & $215 \pm 85$ & $3.4 \pm 1.7$ & $82 \pm 78$ \\
\hline & $\begin{array}{l}\text { Reference } \\
\text { values* }\end{array}$ & & & 0.6 & - & $0-15$ & - & 0.9 & 1.3 & 14 & 1.1 & $200 / 400^{* *}$ & 1.4 & 40 \\
\hline
\end{tabular}


Table 12 continued

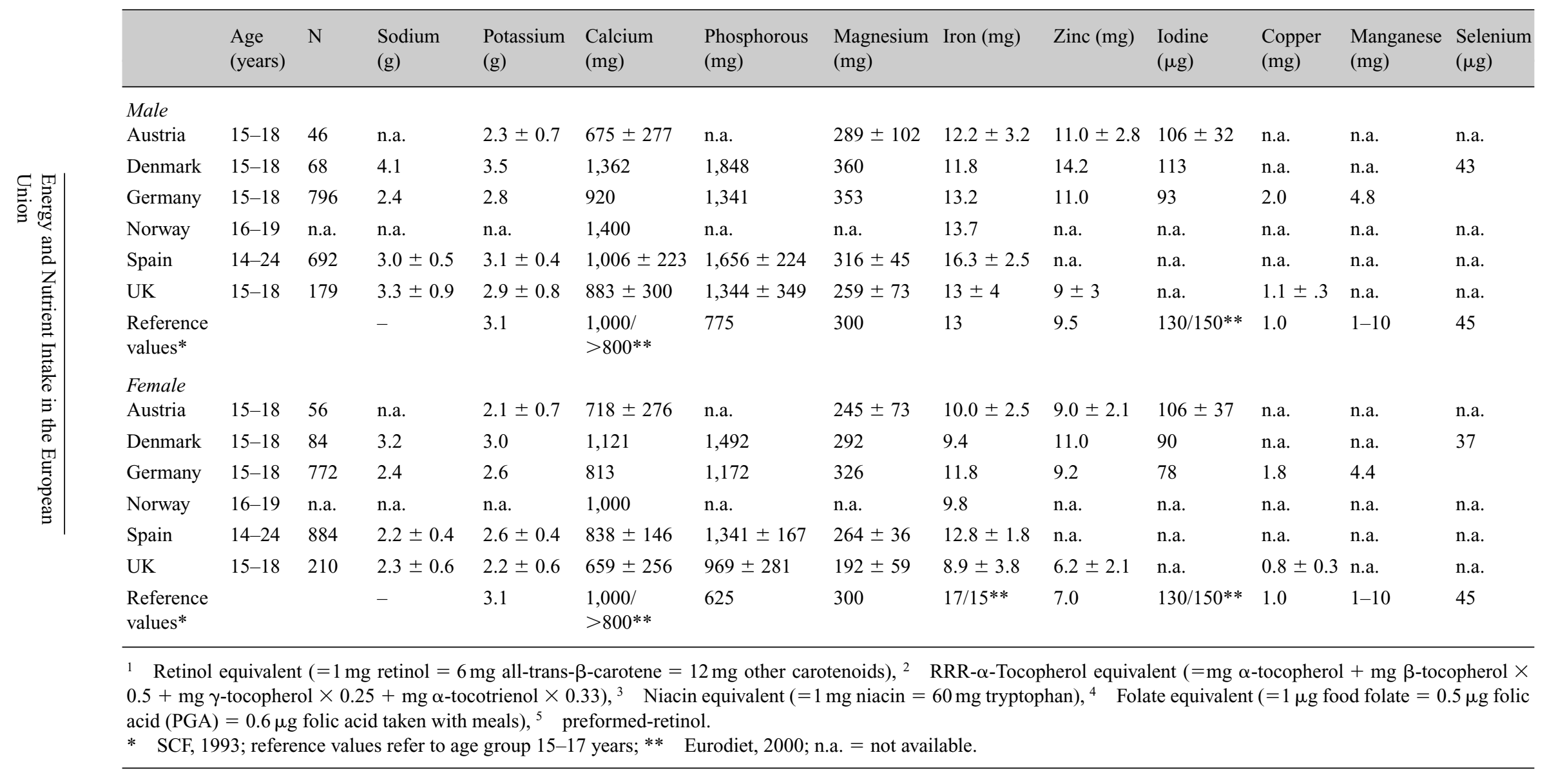


corresponded to the guidelines. Adolescents of all other countries had a mean intake above the population reference intakes recommended by the SCF (1993).

Apart from Denmark and the UK, the mean folate intake was below the recommended level of the SCF (1993) in both male and female adolescents. Compared to the reference values of Eurodiet $(400 \mu \mathrm{g} /$ day) the average folate intake was insufficient in adolescents of all countries.

\section{Minerals}

The sodium intake in adolescents was only assessed in Denmark, Germany, the UK and Spain. Denmark had in the male as well as in the female group the highest average estimated intake. In the male group it was higher than $4 \mathrm{~g} /$ day (table 12). The average potassium intake was not sufficient in female adolescents of all countries, in male adolescents it was below the recommended level in Austria, Germany and the UK. Norway did not have intake data for potassium. The supply of calcium was on average very good in adolescents of the participating countries. Apart from Austrian male and female adolescents and female adolescents of the UK, the mean intake of this nutrient was above the recommended level of Eurodiet (2000) at least $800 \mathrm{mg} /$ day, and in some of these countries it was even above the recommendation of the SCF of $1,000 \mathrm{mg} /$ day. An insufficient average intake of magnesium was found in both male and female adolescents in Austria and the UK. In Danish and Spanish female adolescents it was below the recommended level as well. The average iron intake was not sufficient in females of all countries. In the male group it was too low in Austria and Denmark. The intake of iodine was examined in Austrian, Danish and German adolescents. In all these countries the mean intake of iodine was insufficient.

\section{Energy and Nutrient Intake in European Adults}

All of the participating countries had energy and nutrient intake data of adults (table 13). The age categorisation in the countries was not uniform and also the methods used were not consistent among the countries. The assessment of most of the presented data was accomplished in the preceding decade and the current decade. Only the data of Belgium was from the early 1980s and has to be treated cautiously when making comparisons between the countries.

\section{Energy and Macronutrients}

The energy intake was on average higher in men than in women and usually decreased with increasing age or stayed at a relatively consistent level (tables 14a and 14b). Only in German adults and in Portuguese men the opposite tendency was observed. The average share of protein in total energy intake in European men was comparable to that in women of the same age classes. The highest average proportion of protein in women was found in Portugal (18-19 \%E) and France (18\%). Also in Finnish and Spanish women, as well as in Austrian women aged 65 years or more, and in women of the UK older than 34, the average intake of protein was with $17 \%$ E relatively high. In men, the highest proportions of protein intake were found in Portugal, the UK (older than 34 years), France and Austria (older than 64 years).

The average carbohydrate intake in European adults was low. Apart from Norway, European men of all age groups had a mean carbohydrate intake below $50 \% \mathrm{E}$. An intake of at least $55 \% \mathrm{E}$ is recommended [Eurodiet, 2000]. In Belgium, France and Greece they even had a proportion below $40 \% \mathrm{E}$. On average, women had a slightly higher share of carbohydrates in their daily diet. Again, the lowest carbohydrate intake was found in Greece, Belgium and France (38-41\%E) and the highest intake in Norwegian women. The mean proportion of sucrose in total energy intake was relatively low in European men. In Austria, Denmark, Finland and Sweden it did not on average exceed the upper level proposed by the WHO (2003). The highest mean proportion in men was found in young Hungarian men $(15 \% \mathrm{E})$ and in young men of the UK $(17 \% \mathrm{E})$. It has, however, to be considered that in the UK the proportion of macronutrients was based on total food energy (excl. alcohol). Apart from the UK, the mean share of sucrose in energy intake was higher in European women than in men of the same age groups. The highest average sucrose intake was found in Hungarian women with $16-18 \% \mathrm{E}$.

As a consequence of the low proportion of carbohydrates, the average intake of dietary fibre was low in European adults, especially in women. The highest mean intakes of dietary fibre in women were found in Germany (22-26g/day) and Portugal (22-25 g/day). European men had on average a higher intake of dietary fibre than women. In most countries the mean intake was above $20 \mathrm{~g} /$ day, but still below the recommended $25 \mathrm{~g} /$ day. The highest intakes were found in German men of the last age group, as well as in Norwegian and Portuguese men. The average intake in adults of the UK 
Table 13. Method and period of dietary assessment in adults of European countries

\begin{tabular}{|c|c|c|c|}
\hline Country & Age group & Method & Year of survey \\
\hline Austria & $18-\geq 65$ years & 24-hour-recall & 1998-2001 \\
\hline Belgium & $25-75$ years & 24-hour-recall & 1979-1984 \\
\hline Denmark & 19-64 years & $\begin{array}{l}\text { 7-day-record, personal } \\
\text { interview }\end{array}$ & 1995 \\
\hline Finland & 25-64 years & $\begin{array}{l}\text { 48-hour-recall (using } \\
\text { personal interview) }\end{array}$ & 2002 \\
\hline France & $\begin{array}{l}45-60 \text { years }(\mathrm{m}) \\
35-60 \text { years }(\mathrm{f})\end{array}$ & 24-hour-recalls (6/year) & 1994-2002 \\
\hline Germany & 19-64 years & HBS & 1998 \\
\hline Greece & 25-64 years & Semi-quantitative FFQ & $\begin{array}{l}\text { 1994-1999 (EPIC data } \\
\text { collected at national level) }\end{array}$ \\
\hline Hungary & $\begin{array}{l}18-34 \text { years } \\
35-59 \text { years }(\mathrm{m}) \\
35-54 \text { years }(\mathrm{f})\end{array}$ & $3 \times 24$-hour-records & 1992-1994 \\
\hline Italy & 18-64 years & $\begin{array}{l}\text { 7-day-record, personal } \\
\text { interview }\end{array}$ & 1994-1996 \\
\hline Norway & $20-59$ years & FFQ & 1997 \\
\hline \multirow[t]{2}{*}{ Portugal } & $18-29$ years & $\begin{array}{l}\text { 4-day-record semi- } \\
\text { quantitative FFQ }\end{array}$ & 2001 \\
\hline & $\geq 40$ years & $\begin{array}{l}\text { 7-day-record semi- } \\
\text { quantitative FFQ }\end{array}$ & 1995-1998 \\
\hline Spain $^{1}$ & $25-60$ years & $\begin{array}{l}\text { Repeated 24-hour-recalls } \\
\text { 3-day-record FFQ }\end{array}$ & 1990-1998 \\
\hline Sweden & $18-74$ years & 7-day-record & 1997-1998 \\
\hline UK & 19-64 years & 7-day-record & $2000-2001$ \\
\hline
\end{tabular}

1 The data for Spain was derived from different studies, where different methods were used.

was indicated as non-starch polysaccharides (NSP) and can thus not be directly compared to that of the other countries. The WHO (2003) recommends an intake of NSP of at least $20 \mathrm{mg} /$ day. This level was not reached in men and women of any age groups. In most of the participating countries the average fat intake was high. In men it was only below the upper level of $30 \% \mathrm{E}$ of Eurodiet (2000) in Portuguese older than 40 years. The highest proportion of fat in total energy intake was found in Greek men (44-46 \%E). In European women the average fat intake was relatively high as well. The lowest intakes were found in Norwegian and Portuguese women, the highest again in Greece with $46-48 \% \mathrm{E}$ followed by Belgium ( $42 \% \mathrm{E})$, and France and Spain with $39 \% \mathrm{E}$. The high fat intake in Greece is mainly a result of the general high olive oil consumption.

In addition to this high total fat intake in European countries, the relative proportion of SFA was considerable in this population group as well. The highest proportions were found, in both men and women, in Austrian and Belgian adults. In Italian adults, as well as in Portuguese adults the mean SFA intake was relatively low.

Despite a large proportion of SFA, the mean intake of PUFA was within the normal range in Austrian and Belgian adults. Belgian adults even had the highest proportion of PUFA in total energy intake, followed by German men and UK women (19-34 years). The lowest proportion was found in Hungarian men and women.

The high average intake of fat in European adults was accompanied by a high cholesterol intake, especially in men. The highest intakes were found in Hungarian young men and French men with an average of more than $600 \mathrm{mg} /$ day, but also in the older age group of Hungarian men it was relatively high with around 
Table 14a. Intake of energy and macronutrients (mean \pm SD) in adults of European countries (men)

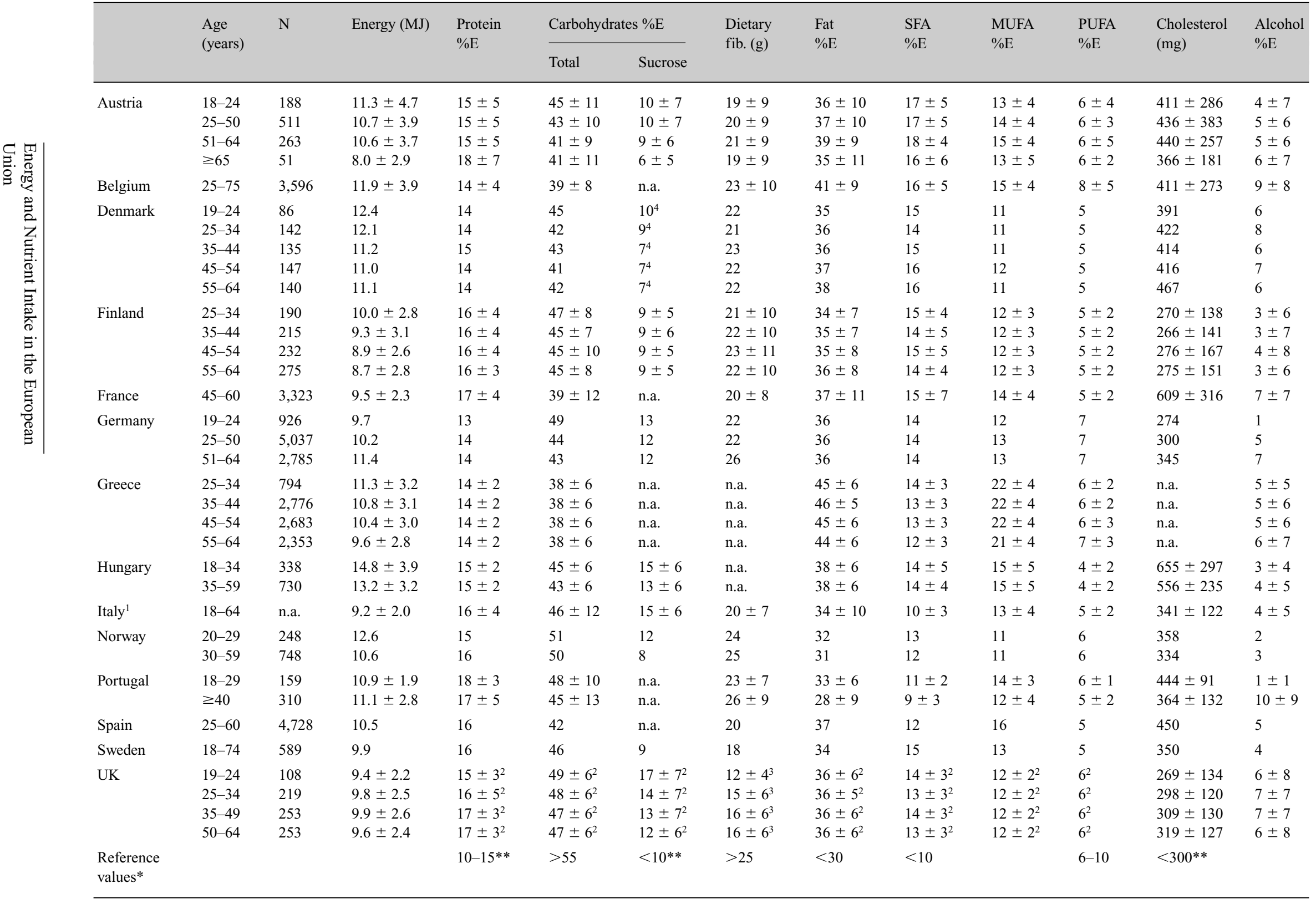

1 Men and women, ${ }^{2} \%$ of total food energy (excl. alcohol), ${ }^{3}$ Non-starchy polysaccharides, ${ }^{4}$ added sugar.

* Eurodiet, 2000; ** WHO, 2003; n.a. $=$ not available. 
Table 14b. Intake of energy and macronutrients (mean \pm SD) in adults of European countries (women)

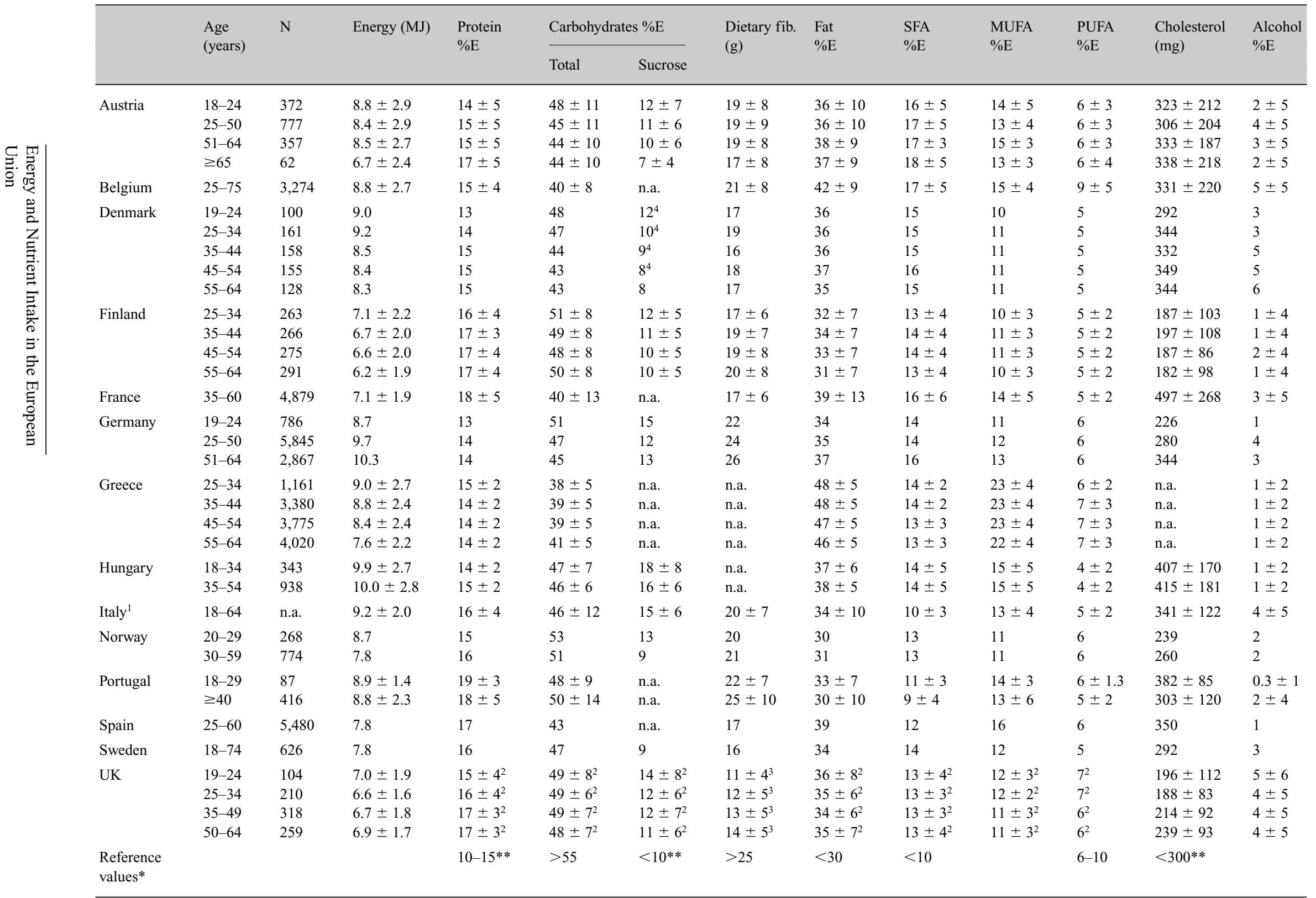

1 Men and women, ${ }^{2} \%$ of total food energy (excl. alcohol), ${ }^{3}$ Non-starchy polysaccharides, ${ }^{4}$ added sugar.

* Eurodiet, 2000; ** WHO, 2003; n.a. = not available. 
$550 \mathrm{mg} /$ day. In most countries, the mean cholesterol intake of men was between 300 and $470 \mathrm{mg}$ /day. Only in Finnish men and in young men of the UK (19-34 years) it was below the upper level of $300 \mathrm{mg} /$ day indicated by the WHO (2003). In women the cholesterol intake was on average lower than in men. The highest intake was found in France with about $500 \mathrm{mg} /$ day, followed by Hungary with a mean intake slightly above $400 \mathrm{mg}$ /day. A particularly low cholesterol intake was observed in Finnish women. Also in adults of the UK, Norway and in German young women it was clearly below the upper level of the WHO (2003).

The mean proportion of alcohol was higher in men than in women. On average it was between 1 and $6 \% \mathrm{E}$ in women, and between 1 and $10 \% \mathrm{E}$ in men. The highest alcohol intake in men was found in Portuguese older than 40 years, followed by Belgian men. In women the mean alcohol intake was relatively high in Denmark as well as in the UK.

\section{Vitamins}

Tables $15 \mathrm{a}$ and $15 \mathrm{~b}$ show that the supply of vitamins in European adults was in general relatively good. The average vitamin A intake was above the recommendation of the SCF (1993) in both men and women. Also the supply of $\beta$-carotene was relatively good in most of the examined European adults. An average intake below $2 \mathrm{mg} /$ day was found in men and women in Sweden and the UK, as well as in Spanish men, Finnish men of the last age group (55-64 years) and German young men (19-14 years). For vitamin $\mathrm{D}$, the SCF does not indicate any exact recommendation, but a range of $1-10 \mu \mathrm{g} /$ day. On average, the vitamin $\mathrm{D}$ intake was higher in men than in women. The lowest intakes in women were found in the UK and in Sweden, with an average of less than $2 \mu \mathrm{g}$ /day. Compared to Swedish women, the mean intake was relatively high in their male compatriots with $6.3 \mu \mathrm{g}$ /day. In Finnish men aged 45-64 years it was even higher with 6.1-7.3 $\mu \mathrm{g} /$ day. Also in Norwegian men and in Austrian men older than 64 years the mean vitamin D intake was relatively high with more than $5 \mu \mathrm{g} /$ day. The intake of vitamin $E$ was on average higher in European men than in women as well, but there was no noticeable difference between the age groups. The lowest average intakes in men and women were found in Denmark, Hungary, Portugal and Spain.

The supply of riboflavin was relatively good in European adults. A mean intake below the reference values of the SCF was only found in Austrian men and women older than 64 and in young German men (19-24 years). The mean intake of thiamine, niacin, vitamin $\mathrm{B}_{6}$ and cobalamin was above the recommended level in adults of all participating countries. The mean folate intake was in general above the recommended minimum level of $200 \mu \mathrm{g} /$ day indicated by the SCF (1993). However, comparing the average intake data of this vitamin with the recommendation of Eurodiet ( $400 \mu \mathrm{g} /$ day) shows that the supply of folate has to be considered as insufficient in men and women of all countries and age groups. The mean supply of vitamin C can - on the basis of the recommendation of the SCF (1993) - be regarded as sufficient as well.

\section{Minerals}

The relatively high estimated sodium intake among the participants, especially among men, is typical for the average diet in industrialised countries. The highest mean estimated intakes were found in Hungary with 8.8-9.5 g/day in men and 6.1-6.4 g/day in women. Also in Italian adults the average estimated sodium intake was relatively high with $5.3 \mathrm{~g}$ /day. Apart from Hungary, the women of all participating countries had a mean intake which was within the acceptable range of intake indicated by the SCF (1993) (tables 16a and 16b).

The mean intake of potassium in men was sufficient and on average higher than in women. It was only below the recommended level of the SCF (1993) in Austrian men, and in the youngest age group in men of Germany and the UK (19-24 years). In women an insufficient intake was more prevalent than in men and was observed in Austria, Denmark, Hungary, Spain and the UK, as well as in the youngest age group of German women (19-24 years). The highest intake was found in Portuguese young women, followed by German women older than 25 years. The mean supply of calcium was relatively good in European adults. The average intake of this nutrient was below the recommended level of at least $800 \mathrm{mg}$ /day [Eurodiet, 2000] in Austrian men and women older than 64 years, in Hungarian women of both age groups and Hungarian men older than 35 years, as well as in women of the UK aged 19-34 years. Men had on average a higher calcium intake than women. Apart from Germany and the UK, the mean intake decreased with increasing age.

The mean supply of iron can be regarded as sufficient in men. There was no age group of any country which had an intake below the population reference intake of $9 \mathrm{mg} /$ day [SCF, 1993]. Women have higher requirements than men, but had on average lower intakes. Apart from 
Table 15a. Vitamin intake (mean $\pm \mathrm{SD}$ ) in adults of European countries (men)

\begin{tabular}{|c|c|c|c|c|c|c|c|c|c|c|c|c|c|}
\hline & $\begin{array}{l}\text { Age } \\
\text { (years) }\end{array}$ & $\mathrm{N}$ & $\begin{array}{l}\text { Vitamin } A^{1} \\
(\mathrm{mg})\end{array}$ & $\begin{array}{l}\beta \text {-Caro- } \\
\text { tene }(\mathrm{mg})\end{array}$ & $\begin{array}{l}\text { Vitamin D } \\
(\mu g)\end{array}$ & $\begin{array}{l}\text { Vitamin } E^{2} \\
(\mathrm{mg})\end{array}$ & $\begin{array}{l}\text { Thiamine } \\
(\mathrm{mg})\end{array}$ & $\begin{array}{l}\text { Riboflavin } \\
(\mathrm{mg})\end{array}$ & $\begin{array}{l}\text { Niacin }{ }^{3} \\
(\mathrm{mg})\end{array}$ & $\begin{array}{l}\text { Vitamin } B_{6} \\
(\mathrm{mg})\end{array}$ & $\begin{array}{l}\text { Folate }^{4} \\
(\mu g)\end{array}$ & $\begin{array}{l}\text { Cobalamin } \\
(\mu g)\end{array}$ & $\begin{array}{l}\text { Ascorbic } \\
\text { acid (mg) }\end{array}$ \\
\hline \multirow[t]{4}{*}{ Austria } & $18-24$ & 188 & $1.4 \pm 1.5$ & $3.1 \pm 2.8$ & $3.3 \pm 4.1$ & $14.3 \pm 10.3$ & $1.7 \pm 0.9$ & $2.1 \pm 1.5$ & $42 \pm 21$ & $2.6 \pm 2.3$ & $286 \pm 152$ & $8 \pm 9$ & $161 \pm 154$ \\
\hline & $25-50$ & 511 & $1.3 \pm 1.0$ & $3.5 \pm 3.5$ & $4.1 \pm 5.7$ & $14.1 \pm 9.2$ & $1.6 \pm 1.1$ & $2.0 \pm 1.2$ & $39 \pm 17$ & $2.3 \pm 1.6$ & $294 \pm 138$ & $7 \pm 8$ & $156 \pm 130$ \\
\hline & $51-64$ & 263 & $1.4 \pm 1.2$ & $3.9 \pm 4.0$ & $4.9 \pm 6.5$ & $13.8 \pm 8.7$ & $1.5 \pm 0.7$ & $1.9 \pm 1.1$ & $36 \pm 15$ & $2.0 \pm 1.0$ & $277 \pm 123$ & $7 \pm 7$ & $142 \pm 123$ \\
\hline & $\geq 65$ & 51 & $1.3 \pm 2.0$ & $2.7 \pm 2.6$ & $5.4 \pm 7.0$ & $9.0 \pm 4.6$ & $1.1 \pm 0.5$ & $1.3 \pm 0.6$ & $30 \pm 9$ & $1.5 \pm 0.5$ & $217 \pm 115$ & $8 \pm 10$ & $108 \pm 107$ \\
\hline \multirow[t]{5}{*}{ Denmark } & $19-24$ & 86 & 1.3 & 2.6 & 3.2 & 8.4 & 1.5 & 2.3 & 34 & 1.9 & 313 & 7.0 & 65 \\
\hline & $25-34$ & 142 & 1.4 & 3.2 & 3.2 & 9.1 & 1.4 & 2.0 & 37 & 1.8 & 282 & 6.3 & 65 \\
\hline & $35-44$ & 135 & 1.9 & 4.4 & 3.2 & 8.8 & 1.5 & 2.0 & 38 & 1.8 & 329 & 7.1 & 77 \\
\hline & $45-54$ & 147 & 1.5 & 3.3 & 3.7 & 9.0 & 1.3 & 1.9 & 35 & 1.7 & 291 & 6.6 & 88 \\
\hline & $55-64$ & 140 & 1.8 & 2.9 & 3.9 & 9.7 & 1.4 & 2.1 & 35 & 1.6 & 313 & 7.7 & 82 \\
\hline \multirow[t]{4}{*}{ Finland } & $25-34$ & 190 & $1.0 \pm 1.0$ & $2.3 \pm 2.2$ & $4.2 \pm 3.2$ & $12.1 \pm 5.6$ & $1.4 \pm 0.5$ & $2.2 \pm 0.9$ & $34 \pm 15$ & $2.4 \pm 2.9$ & $281 \pm 100$ & $6.9 \pm 5.1$ & $104 \pm 87$ \\
\hline & $35-44$ & 215 & $1.1 \pm 2.4$ & $2.1 \pm 1.9$ & $4.9 \pm 4.8$ & $11.5 \pm 5.2$ & $1.4 \pm 0.6$ & $2.0 \pm 0.9$ & $32 \pm 12$ & $2.0 \pm 0.8$ & $275 \pm 164$ & $6.8 \pm 11$ & $95 \pm 82$ \\
\hline & $45-54$ & 232 & $1.0 \pm 1.2$ & $2.3 \pm 2.4$ & $6.1 \pm 6.8$ & $11.5 \pm 4.9$ & $1.3 \pm 0.5$ & $2.0 \pm 0.8$ & $30 \pm 10$ & $2.0 \pm 0.8$ & $274 \pm 108$ & $7.0 \pm 5.9$ & $87 \pm 67$ \\
\hline & $55-64$ & 275 & $1.0 \pm 1.2$ & $1.9 \pm 2.0$ & $7.3 \pm 7.6$ & $12.1 \pm 6.4$ & $1.4 \pm 0.6$ & $1.9 \pm 0.7$ & $29 \pm 11$ & $1.9 \pm 0.8$ & $267 \pm 108$ & $7.2 \pm 6.1$ & $83 \pm 71$ \\
\hline France & $45-60$ & 3,323 & $0.9 \pm 1.4$ & $3.6 \pm 2.8$ & $2.9 \pm 2.4$ & $11.2 \pm 4.6$ & $1.8 \pm 0.7$ & $1.8 \pm 0.6$ & n.a. & $2.0 \pm 0.5$ & $320 \pm 101$ & $8.2 \pm 6.8$ & $92 \pm 50$ \\
\hline \multirow[t]{3}{*}{ Germany } & $19-24$ & 926 & 1.0 & 1.8 & 2.3 & 15.2 & 1.3 & 1.5 & 26 & 1.6 & 195 & 4.8 & 101 \\
\hline & $25-50$ & 5,037 & 1.2 & 2.2 & 3.5 & 14.8 & 1.4 & 1.6 & 32 & 1.8 & 210 & 6.2 & 96 \\
\hline & $51-64$ & 2,785 & 1.5 & 2.7 & 4.5 & 16.6 & 1.6 & 1.8 & 38 & 2.1 & 254 & 7.7 & 120 \\
\hline \multirow[t]{2}{*}{ Hungary } & $18-34$ & 338 & $1.2 \pm 1.4$ & $2.6 \pm 1.8$ & n.a. & $9.0 \pm 5.1$ & $1.5 \pm 0.5$ & $1.9 \pm 0.8$ & $26 \pm 10$ & $2.4 \pm 0.7$ & n.a. & $7.9 \pm 9.3$ & $101 \pm 70$ \\
\hline & $35-59$ & 730 & $1.0 \pm 1.2$ & $2.7 \pm 1.8$ & n.a. & $7.8 \pm 4.2$ & $1.3 \pm 0.7$ & $1.6 \pm 0.7$ & $25 \pm 8$ & $2.3 \pm 0.6$ & n.a. & $6.3 \pm 6.9$ & $104 \pm 76$ \\
\hline Italy $^{5}$ & $18-64$ & n.a. & $1.2 \pm 1.2$ & $3.0 \pm 1.9$ & $3.1 \pm 2.1$ & $11.2 \pm 5.1$ & $1.1 \pm 0.3$ & $1.6 \pm 0.5$ & $19 \pm 5$ & $2.0 \pm 0.6$ & $297 \pm 98$ & n.a. & $117 \pm 62$ \\
\hline \multirow[t]{2}{*}{ Norway } & $20-29$ & 248 & 1.6 & n.a. & 5.6 & n.a. & 1.7 & 2.3 & 21 & n.a. & n.a. & n.a. & 124 \\
\hline & $30-59$ & 748 & 1.6 & n.a. & 5.9 & n.a. & 1.6 & 1.9 & 20 & n.a. & n.a. & n.a. & 120 \\
\hline \multirow[t]{2}{*}{ Portugal } & $18-29$ & 159 & $1.5 \pm 0.8$ & n.a. & $4.8 \pm 1.8$ & $8.2 \pm 2.2$ & $2.1 \pm 0.4$ & $2.4 \pm 0.6$ & $27 \pm 5$ & $2.4 \pm 0.5$ & $305 \pm 93$ & $10.6 \pm 4.1$ & $125 \pm 48$ \\
\hline & $\geq 40$ & 310 & $1.5 \pm 0.8$ & n.a. & n.a. & $8.7 \pm 2.4$ & n.a. & n.a. & n.a. & n.a. & $296 \pm 90$ & n.a. & n.a. \\
\hline Spain & $25-60$ & 4,728 & $0.7 \pm 0.5$ & $1.8 \pm 1.5$ & $2.4 \pm 2.6$ & $9.1 \pm 6.1$ & $1.8 \pm 0.8$ & $1.8 \pm 1.0$ & $40 \pm 15$ & $2.3 \pm 0.9$ & $267 \pm 108$ & $9.5 \pm 8.5$ & $123 \pm 85$ \\
\hline Sweden & $18-74$ & 589 & 1.3 & 1.7 & 6.2 & $7.8^{6}$ & 1.6 & 1.9 & 39 & 2.2 & 232 & 6.9 & 80 \\
\hline \multirow[t]{4}{*}{ UK } & $19-24$ & 108 & $0.6 \pm 0.4^{7}$ & $1.3 \pm 0.9$ & $3.0 \pm 1.6$ & $10.1 \pm 4.3$ & $1.6 \pm 0.6$ & $1.7 \pm 0.8$ & $40 \pm 12$ & $2.7 \pm 1.0$ & $305 \pm 114$ & $4.5 \pm 1.7$ & $67 \pm 55$ \\
\hline & $25-34$ & 219 & $0.9 \pm 0.7^{7}$ & $1.6 \pm 1.1$ & $4.1 \pm 3.2$ & $11.9 \pm 7.2$ & $2.3 \pm 2.6$ & $2.4 \pm 2.2$ & $49 \pm 30$ & $3.3 \pm 2.2$ & $376 \pm 224$ & $6.2 \pm 4.3$ & $84 \pm 66$ \\
\hline & $35-49$ & 253 & $1.1 \pm 1.4^{7}$ & $1.9 \pm 1.1$ & $4.2 \pm 3.1$ & $14.4 \pm 27.4$ & $2.3 \pm 2.6$ & $2.4 \pm 1.8$ & $47 \pm 16$ & $3.5 \pm 5.1$ & $355 \pm 171$ & $7.4 \pm 7.3$ & $108 \pm 208$ \\
\hline & $50-64$ & 253 & $1.3 \pm 1.3^{7}$ & $2.3 \pm 1.8$ & $4.9 \pm 3.3$ & $15.2 \pm 27.7$ & $2.4 \pm 3.1$ & $2.5 \pm 3.7$ & $46 \pm 16$ & $3.4 \pm 4.6$ & $373 \pm 151$ & $7.6 \pm 6.6$ & $125 \pm 142$ \\
\hline $\begin{array}{l}\text { Reference } \\
\text { values* }\end{array}$ & & & 0.7 & - & $0-10$ & - & 1.1 & 1.6 & 18 & 1.5 & $200 / 400^{* *}$ & 1.4 & 45 \\
\hline
\end{tabular}

1 Retinol equivalent $\left(=1 \mathrm{mg}\right.$ retinol $=6 \mathrm{mg}$ all-trans- $\beta$-carotene $=12 \mathrm{mg}$ other carotenoids) ${ }^{2} \quad$ RRR- $\alpha$-Tocopherol equivalent $(=\mathrm{mg} \alpha$-tocopherol + mg $\beta$-tocopherol $\times$ $0.5+\mathrm{mg} \gamma$-tocopherol $\times 0.25+\mathrm{mg} \alpha$-tocotrienol $\times 0.33),{ }^{3} \quad$ Niacin equivalent $(=1 \mathrm{mg}$ niacin $=60 \mathrm{mg}$ tryptophan $),{ }^{4}$ Folate equivalent $(=1 \mu \mathrm{g}$ food folate $=0.5 \mu \mathrm{g}$ folic acid $(\mathrm{PGA})=0.6 \mu \mathrm{g}$ folic acid taken with meals), ${ }^{5}$ men and women, ${ }^{6} \alpha$-tocopherol, ${ }^{7}$ preformed-retinol.

* SCF, 1993; ** Eurodiet, 2000; n.a. = not available. 
Table 15b. Vitamin intake (mean $\pm \mathrm{SD}$ ) in adults of European countries (women)

\begin{tabular}{|c|c|c|c|c|c|c|c|c|c|c|c|c|c|}
\hline & $\begin{array}{l}\text { Age } \\
\text { (years) }\end{array}$ & $\mathrm{N}$ & $\begin{array}{l}\text { Vitamin } \mathrm{A}^{1} \\
(\mathrm{mg})\end{array}$ & $\begin{array}{l}\beta \text {-Caro- } \\
\text { tene }(\mathrm{mg})\end{array}$ & $\begin{array}{l}\text { Vitamin D } \\
(\mu \mathrm{g})\end{array}$ & $\begin{array}{l}\text { Vitamin } E^{2} \\
(\mathrm{mg})\end{array}$ & $\begin{array}{l}\text { Thiamine } \\
\text { (mg) }\end{array}$ & $\begin{array}{l}\text { Riboflavin } \\
\text { (mg) }\end{array}$ & $\begin{array}{l}\mathrm{Niacin}^{3} \\
(\mathrm{mg})\end{array}$ & $\begin{array}{l}\text { Vitamin } B_{6} \\
(\mathrm{mg})\end{array}$ & Folate $^{4}(\mu \mathrm{g})$ & $\begin{array}{l}\text { Cobalamin } \\
(\mu g)\end{array}$ & $\begin{array}{l}\text { Ascorbic } \\
\text { acid (mg) }\end{array}$ \\
\hline \multirow[t]{4}{*}{ Austria } & $18-24$ & 372 & $1.2 \pm 0.9$ & $3.3 \pm 3.3$ & $3.3 \pm 4.0$ & $12.7 \pm 8.1$ & $1.3 \pm 0.9$ & $1.7 \pm 1.1$ & $29 \pm 14$ & $1.9 \pm 1.6$ & $256 \pm 110$ & $5 \pm 5$ & $127 \pm 106$ \\
\hline & $25-50$ & 777 & $1.3 \pm 1.2$ & $3.8 \pm 4.1$ & $3.7 \pm 5.1$ & $12.9 \pm 8.5$ & $1.3 \pm 0.8$ & $1.7 \pm 0.9$ & $30 \pm 14$ & $1.9 \pm 1.5$ & $264 \pm 120$ & $5 \pm 4$ & $138 \pm 114$ \\
\hline & $51-64$ & 357 & $1.3 \pm 1.3$ & $3.5 \pm 3.6$ & $4.1 \pm 5.8$ & $12.3 \pm 7.6$ & $1.2 \pm 0.7$ & $1.6 \pm 0.9$ & $29 \pm 12$ & $1.7 \pm 0.9$ & $247 \pm 112$ & $5 \pm 7$ & $126 \pm 111$ \\
\hline & $\geq 65$ & 62 & $0.9 \pm 0.7$ & $2.6 \pm 2.1$ & $2.6 \pm 2.5$ & $8.2 \pm 4.6$ & $0.9 \pm 0.4$ & $1.2 \pm 0.5$ & $25 \pm 11$ & $1.3 \pm 0.6$ & $199 \pm 91$ & $4 \pm 3$ & $98 \pm 84$ \\
\hline \multirow[t]{5}{*}{ Denmark } & $19-24$ & 100 & 1.1 & 2.9 & 2.4 & 6.7 & 1.1 & 1.7 & 24 & 1.3 & 244 & 4.9 & 72 \\
\hline & $25-34$ & 161 & 1.2 & 3.2 & 2.7 & 8.0 & 1.1 & 1.6 & 27 & 1.3 & 266 & 5.0 & 82 \\
\hline & $35-44$ & 158 & 1.2 & 3.3 & 2.8 & 6.9 & 1.1 & 1.5 & 28 & 1.3 & 234 & 4.8 & 76 \\
\hline & $45-54$ & 155 & 1.2 & 3.4 & 3.6 & 7.0 & 1.0 & 1.6 & 28 & 1.3 & 248 & 5.3 & 78 \\
\hline & $55-64$ & 128 & 1.4 & 3.7 & 4.0 & 6.9 & 1.0 & 1.6 & 27 & 1.3 & 241 & 5.7 & 82 \\
\hline \multirow[t]{4}{*}{ Finland } & $25-34$ & 263 & $0.8 \pm 0.5$ & $2.5 \pm 2.2$ & $2.9 \pm 2.6$ & $8.9 \pm 3.5$ & $1.0 \pm 0.5$ & $1.6 \pm 0.6$ & $23 \pm 8$ & $1.7 \pm 0.7$ & $214 \pm 73$ & $4.3 \pm 2.7$ & $104 \pm 69$ \\
\hline & $35-44$ & 266 & $0.9 \pm 0.8$ & $2.8 \pm 2.9$ & $3.5 \pm 3.8$ & $8.6 \pm 3.5$ & $1.0 \pm 0.4$ & $1.5 \pm 0.6$ & $22 \pm 7$ & $1.5 \pm 0.5$ & $219 \pm 86$ & $4.7 \pm 3.2$ & $98 \pm 72$ \\
\hline & $45-54$ & 275 & $1.1 \pm 1.6$ & $2.7 \pm 3.0$ & $3.7 \pm 3.9$ & $8.8 \pm 3.9$ & $1.0 \pm 0.4$ & $1.5 \pm 0.6$ & $22 \pm 7$ & $1.5 \pm 0.6$ & $233 \pm 115$ & $5.2 \pm 6.7$ & $106 \pm 69$ \\
\hline & $55-64$ & 291 & $1.0 \pm 1.3$ & $2.7 \pm 2.6$ & $4.8 \pm 5.3$ & $9.5 \pm 5.8$ & $1.1 \pm 0.4$ & $1.6 \pm 0.7$ & $21 \pm 7$ & $1.5 \pm 0.6$ & $229 \pm 110$ & $5.2 \pm 5.5$ & $112 \pm 71$ \\
\hline France & $35-60$ & 4,879 & $0.7 \pm 1.0$ & $3.4 \pm 2.8$ & $2.4 \pm 2.1$ & $9.5 \pm 4.0$ & $1.5 \pm 0.6$ & $1.5 \pm 0.5$ & n.a. & $1.6 \pm 0.5$ & $272 \pm 93$ & $6.1 \pm 5.2$ & $88 \pm 46$ \\
\hline \multirow[t]{3}{*}{ Germany } & $19-24$ & 786 & 1.0 & 2.8 & 2.1 & 11.9 & 1.2 & 1.3 & 23 & 1.4 & 194 & 3.6 & 116 \\
\hline & $25-50$ & 5,845 & 1.4 & 3.4 & 2.5 & 12.7 & 1.4 & 1.5 & 32 & 1.7 & 227 & 5.3 & 129 \\
\hline & $51-64$ & 2,867 & 1.7 & 4.0 & 3.0 & 14.8 & 1.4 & 1.7 & 34 & 1.9 & 266 & 6.1 & 157 \\
\hline \multirow[t]{2}{*}{ Hungary } & $18-34$ & 343 & $0.9 \pm 0.8$ & $2.4 \pm 1.7$ & n.a. & $7.3 \pm 3.9$ & $1.0 \pm 0.4$ & $1.3 \pm 0.5$ & $17 \pm 6$ & $1.7 \pm 0.6$ & n.a. & $4.3 \pm 4.3$ & $97 \pm 64$ \\
\hline & $35-54$ & 938 & $1.0 \pm 1.0$ & $2.8 \pm 2.1$ & n.a. & $7.4 \pm 4.0$ & $1.0 \pm 0.3$ & $1.3 \pm 0.5$ & $18 \pm 6$ & $1.8 \pm 0.6$ & n.a. & $4.8 \pm 6.5$ & $95 \pm 56$ \\
\hline Italy $^{5}$ & $18-64$ & n.a. & $1.2 \pm 1.2$ & $3.0 \pm 1.9$ & $3.1 \pm 2.1$ & $11.2 \pm 5.1$ & $1.1 \pm 0.3$ & $1.6 \pm 0.5$ & $19 \pm 5$ & $2.0 \pm 0.6$ & $297 \pm 98$ & n.a. & $117 \pm 62$ \\
\hline \multirow[t]{2}{*}{ Norway } & $20-29$ & 268 & 1.3 & n.a. & 3.4 & n.a. & 1.2 & 1.6 & 14 & n.a. & n.a. & n.a. & 111 \\
\hline & $30-59$ & 774 & 1.5 & n.a. & 4.2 & n.a. & 1.2 & 1.5 & 14 & n.a. & n.a. & n.a. & 119 \\
\hline \multirow[t]{2}{*}{ Portugal } & $18-29$ & 87 & $1.7 \pm 1.0$ & n.a. & $4.6 \pm 1.6$ & $7.8 \pm 2.2$ & $1.8 \pm 0.3$ & $2.1 \pm 0.5$ & $23 \pm 4$ & $2.1 \pm 0.5$ & $277 \pm 96$ & $9.2 \pm 3.8$ & $133 \pm 53$ \\
\hline & $\geq 40$ & 416 & $1.7 \pm 1.0$ & n.a. & n.a. & $8.2 \pm 2.8$ & n.a. & n.a. & n.a. & n.a. & $282 \pm 106$ & - & - \\
\hline Spain & $25-60$ & 5,480 & $0.7 \pm 0.5$ & $2.0 \pm 1.8$ & $2.0 \pm 2.3$ & $8.3 \pm 5.2$ & $1.5 \pm 0.6$ & $1.7 \pm 0.8$ & $33 \pm 13$ & $2.0 \pm 0.8$ & $252 \pm 103$ & $7.1 \pm 7.1$ & $136 \pm 88$ \\
\hline Sweden & $18-74$ & 626 & 1.1 & 1.9 & 4.9 & $6.8^{6}$ & 1.3 & 1.6 & 31 & 1.9 & 217 & 6.0 & 93 \\
\hline \multirow[t]{4}{*}{ UK } & $19-24$ & 104 & $0.6 \pm 0.6^{7}$ & $1.4 \pm 1.9$ & $2.9 \pm 2.5$ & $9.4 \pm 9.2$ & $1.6 \pm 1.0$ & $1.5 \pm 0.8$ & $31 \pm 10$ & $2.1 \pm 0.9$ & $248 \pm 109$ & $4.1 \pm 2.1$ & $96 \pm 134$ \\
\hline & $25-34$ & 210 & $0.6 \pm 0.7^{7}$ & $1.6 \pm 1.2$ & $2.7 \pm 2.0$ & $8.6 \pm 4.7$ & $1.6 \pm 1.3$ & $1.5 \pm 0.6$ & $29 \pm 9$ & $2.3 \pm 3.2$ & $249 \pm 113$ & $4.0 \pm 2.2$ & $85 \pm 85$ \\
\hline & $35-49$ & 318 & $0.8 \pm 0.6^{7}$ & $1.8 \pm 1.5$ & $3.5 \pm 2.9$ & $14.3 \pm 40.1$ & $2.0 \pm 5.7$ & $2.1 \pm 5.5$ & $34 \pm 12$ & $3.4 \pm 9.8$ & $280 \pm 123$ & $5.5 \pm 6.4$ & $123 \pm 299$ \\
\hline & $50-64$ & 259 & $1.0 \pm 0.8^{7}$ & $2.0 \pm 1.2$ & $5.1 \pm 4.1$ & $23.2 \pm 60.5$ & $2.3 \pm 6.6$ & $2.5 \pm 6.6$ & $35 \pm 12$ & $3.3 \pm 8.3$ & $359 \pm 917$ & $6.1 \pm 3.7$ & $127 \pm 161$ \\
\hline $\begin{array}{l}\text { Reference } \\
\text { values* }\end{array}$ & & & 0.6 & - & $0-10$ & - & 0.9 & 1.3 & 14 & 1.1 & $200 / 400^{* *}$ & 1.4 & 45 \\
\hline
\end{tabular}

1 Retinol equivalent $(=1 \mathrm{mg}$ retinol $=6 \mathrm{mg}$ all-trans- $\beta$-carotene $=12 \mathrm{mg}$ other carotenoids $){ }^{2} \quad$ RRR- $\alpha$-Tocopherol equivalent $(=\mathrm{mg} \alpha$-tocopherol + mg $\beta$-tocopherol $\times$ $0.5+\mathrm{mg} \gamma$-tocopherol $\times 0.25+\mathrm{mg} \alpha$-tocotrieno $\times 10.33),{ }^{3}$ Niacin equivalent $(=1 \mathrm{mg}$ niacin $=60 \mathrm{mg}$ tryptophan $),{ }^{4}$ Folate equivalent $(=1 \mu \mathrm{g}$ food folate $=0.5 \mu \mathrm{g}$ folic acid $(\mathrm{PGA})=0.6 \mu \mathrm{g}$ folic acid taken with meals), ${ }^{5}$ men and women, ${ }^{6} \alpha$-tocopherol, ${ }^{7}$ preformed-retinol.

* SCF, 1993; ** Eurodiet, 2000; n.a = not available. 
Table16a. Mineral intake (mean \pm SD) in adults of European countries (men)

\begin{tabular}{|c|c|c|c|c|c|c|c|c|c|c|c|c|c|}
\hline & $\begin{array}{l}\text { Age } \\
\text { (years) }\end{array}$ & $\mathrm{N}$ & $\begin{array}{l}\text { Sodium } \\
(\mathrm{g})\end{array}$ & $\begin{array}{l}\text { Potassium } \\
(\mathrm{g})\end{array}$ & $\begin{array}{l}\text { Calcium } \\
(\mathrm{mg})\end{array}$ & $\begin{array}{l}\text { Phosphorous } \\
\text { (mg) }\end{array}$ & $\begin{array}{l}\text { Magnesium } \\
(\mathrm{mg})\end{array}$ & $\begin{array}{l}\text { Iron } \\
(\mathrm{mg})\end{array}$ & $\begin{array}{l}\text { Zinc } \\
(\mathrm{mg})\end{array}$ & $\begin{array}{l}\text { Iodine } \\
(\mu \mathrm{g})\end{array}$ & $\begin{array}{l}\text { Copper } \\
(\mathrm{mg})\end{array}$ & $\begin{array}{l}\text { Manganese } \\
(\mathrm{mg})\end{array}$ & $\begin{array}{l}\text { Selenium } \\
(\mu \mathrm{g})\end{array}$ \\
\hline \multirow[t]{4}{*}{ Austria } & $18-24$ & 188 & n.a. & $3.0 \pm 1.4$ & $1,045 \pm 588$ & n.a. & $385 \pm 169$ & $15.6 \pm 6.7$ & $13.3 \pm 5.5$ & $160 \pm 234$ & $2.3 \pm 0.8$ & $4.5 \pm 2.6$ & n.a. \\
\hline & $25-50$ & 511 & n.a. & $3.1 \pm 1.7$ & $1,000 \pm 582$ & n.a. & $379 \pm 154$ & $15.5 \pm 7.8$ & $12.5 \pm 4.9$ & $165 \pm 254$ & $2.3 \pm 0.8$ & $4.6 \pm 2.3$ & n.a. \\
\hline & $51-64$ & 263 & n.a. & $3.0 \pm 1.1$ & $981 \pm 528$ & n.a. & $362 \pm 129$ & $15.6 \pm 6.4$ & $12.8 \pm 4.9$ & $135 \pm 74$ & $2.2 \pm 0.8$ & $4.7 \pm 2.3$ & n.a. \\
\hline & $\geq 65$ & 51 & n.a. & $2.4 \pm 0.8$ & $661 \pm 504$ & n.a. & $286 \pm 95$ & $12.9 \pm 4.4$ & $11.7 \pm 4.0$ & $109 \pm 59$ & $2.1 \pm 0.8$ & $4.8 \pm 2.4$ & n.a. \\
\hline \multirow[t]{5}{*}{ Denmark } & $19-24$ & 86 & 4.6 & 3.6 & 1,379 & 1,893 & 396 & 12.3 & 15 & 110 & n.a. & n.a. & 46 \\
\hline & $25-34$ & 142 & 4.2 & 3.7 & 1,121 & 1,747 & 403 & 12.1 & 14.6 & 166 & n.a. & n.a. & 47 \\
\hline & $35-44$ & 135 & 3.9 & 4 & 1,027 & 1,708 & 408 & 12.6 & 14.9 & 161 & n.a. & n.a. & 48 \\
\hline & $45-54$ & 147 & 3.8 & 3.8 & 983 & 1,614 & 394 & 11.8 & 13.9 & 160 & n.a. & n.a. & 47 \\
\hline & $55-64$ & 140 & 3.4 & 3.8 & 1,051 & 1,674 & 383 & 11.6 & 13.8 & 147 & n.a. & n.a. & 48 \\
\hline \multirow[t]{4}{*}{ Finland } & $25-34$ & 190 & $4.1 \pm 1.2$ & $4.1 \pm 1.2$ & $1,391 \pm 623$ & $1,878 \pm 600$ & $410 \pm 148$ & $13.3 \pm 5.2$ & $12.7 \pm 7.1$ & $320 \pm 116$ & n.a. & n.a. & $83 \pm 30$ \\
\hline & $35-44$ & 215 & $3.9 \pm 1.4$ & $4.0 \pm 1.3$ & $1,203 \pm 607$ & $1,761 \pm 643$ & $409 \pm 148$ & $13.1 \pm 5.8$ & $12.5 \pm 3.9$ & $284 \pm 112$ & n.a. & n.a. & $81 \pm 28$ \\
\hline & $45-54$ & 232 & $3.8 \pm 1.4$ & $4.1 \pm 1.2$ & $1,137 \pm 535$ & $1,754 \pm 573$ & $411 \pm 124$ & $13.0 \pm 5.5$ & $11.8 \pm 3.3$ & $270 \pm 107$ & n.a. & n.a. & $78 \pm 27$ \\
\hline & $55-64$ & 275 & $3.9 \pm 1.5$ & $3.9 \pm 1.1$ & $1,075 \pm 509$ & $1,733 \pm 603$ & $392 \pm 120$ & $13.4 \pm 5.8$ & $9.1 \pm 3.3$ & $275 \pm 108$ & n.a. & n.a. & $75 \pm 31$ \\
\hline France & $45-60$ & 3,323 & $3.5 \pm 1.1$ & n.a. & $936 \pm 336$ & n.a. & $322 \pm 86$ & $14 \pm 4$ & n.a. & n.a. & n.a. & n.a. & n.a. \\
\hline \multirow[t]{3}{*}{ Germany } & $19-24$ & 926 & 2.8 & 2.8 & 880 & 1,284 & 336 & 12.3 & 10.6 & 86 & 1.9 & 4.2 & n.a. \\
\hline & $25-50$ & 5,037 & 3.4 & 3.2 & 889 & 1,385 & 384 & 13.5 & 11.1 & 97 & 2.2 & 4.4 & n.a. \\
\hline & $51-64$ & 2,785 & 4.2 & 3.9 & 965 & 1,555 & 443 & 16 & 12.6 & 117 & 2.5 & 5.2 & n.a. \\
\hline \multirow[t]{2}{*}{ Hungary } & $18-34$ & 338 & $9.5 \pm 3.0$ & $3.5 \pm 1.0$ & $868 \pm 452$ & n.a. & $482 \pm 133$ & $16.2 \pm 6.6$ & $13.5 \pm 4.7$ & n.a. & $2.9 \pm 2.5$ & n.a. & n.a. \\
\hline & $35-59$ & 730 & $8.8 \pm 2.8$ & $3.2 \pm 0.9$ & $659 \pm 348$ & n.a. & $429 \pm 114$ & $14.4 \pm 4.7$ & $11.9 \pm 3.7$ & n.a. & $2.9 \pm 2.8$ & n.a. & n.a. \\
\hline Italy $^{1}$ & $18-64$ & n.a. & $5.2 \pm 2.2$ & $3.1 \pm 0.8$ & $893 \pm 288$ & $1,326 \pm 316$ & $212 \pm 57$ & $13.1 \pm 3.9$ & $11.7 \pm 3.2$ & n.a. & $1.5 \pm 0.6$ & n.a. & $43 \pm 18$ \\
\hline \multirow[t]{2}{*}{ Norway } & $20-29$ & 248 & n.a. & n.a. & 1,300 & n.a. & n.a. & 13.0 & n.a. & n.a. & n.a. & n.a. & n.a. \\
\hline & $30-59$ & 748 & n.a. & n.a. & 1,000 & n.a. & n.a. & 12.1 & n.a. & n.a. & n.a. & n.a. & n.a. \\
\hline \multirow[t]{2}{*}{ Portugal } & $18-29$ & 159 & $2.5 \pm 0.6$ & $3.6 \pm 0.8$ & $998 \pm 318$ & $1,689 \pm 339$ & $363 \pm 74$ & $15.6 \pm 3.4$ & $15.2 \pm 3.0$ & $104 \pm 53$ & $1.8 \pm 0.5$ & n.a. & $151 \pm 92$ \\
\hline & $\geq 40$ & 310 & n.a. & n.a. & $862 \pm 337$ & n.a. & n.a. & $19 \pm 5$ & n.a. & n.a. & n.a. & n.a. & n.a. \\
\hline Spain & $25-60$ & 4,728 & 2.9 & 3.3 & 867 & 1,441 & 319 & 15.2 & n.a. & n.a. & n.a. & n.a. & n.a. \\
\hline Sweden & $18-74$ & 589 & 3.6 & 3.5 & 1,070 & 1,570 & 345 & 12.3 & 12.6 & n.a. & n.a. & n.a. & 36 \\
\hline \multirow[t]{4}{*}{ UK } & $19-24$ & 108 & $3.3 \pm 1.1$ & $2.8 \pm 0.7$ & $867 \pm 325$ & $1,341 \pm 319$ & $260 \pm 73$ & $11.5 \pm 4.6$ & $9.2 \pm 2.5$ & $167 \pm 70$ & $1.2 \pm 0.3$ & $2.5 \pm 0.8$ & n.a. \\
\hline & $25-34$ & 219 & $3.4 \pm 1.1$ & $3.3 \pm 1.0$ & $1,030 \pm 606$ & $1,550 \pm 727$ & $311 \pm 105$ & $13.9 \pm 7.5$ & $10.7 \pm 4.4$ & $223 \pm 122$ & $1.4 \pm 0.7$ & $3.2 \pm 1.3$ & n.a. \\
\hline & $35-49$ & 253 & $3.3 \pm 1.0$ & $3.5 \pm 0.9$ & $1,049 \pm 359$ & $1,524 \pm 429$ & $322 \pm 106$ & $14.1 \pm 12.9$ & $11.4 \pm 8.4$ & $226 \pm 93$ & $1.6 \pm 1.0$ & $3.6 \pm 3.1$ & n.a. \\
\hline & $50-64$ & 253 & $3.2 \pm 1.0$ & $3.6 \pm 1.0$ & $1,035 \pm 331$ & $1,508 \pm 403$ & $320 \pm 103$ & $15.2 \pm 13.2$ & $10.8 \pm 4.2$ & $235 \pm 85$ & $1.6 \pm 0.9$ & $3.8 \pm 1.5$ & n.a. \\
\hline $\begin{array}{l}\text { Reference } \\
\text { values* }\end{array}$ & & & $0.6-3.5$ & 3.1 & $\begin{array}{l}700 / \\
>800^{* *}\end{array}$ & 550 & $150-500$ & 9 & 9.5 & $\begin{array}{l}130 / \\
150^{* *}\end{array}$ & 1.1 & $1-10$ & 55 \\
\hline
\end{tabular}

1 Men and women.

* SCF, 1993; ** Eurodiet, 2000; n.a. = not available. 
Table 16b. Mineral intake (mean \pm SD) in adults of European countries (women)

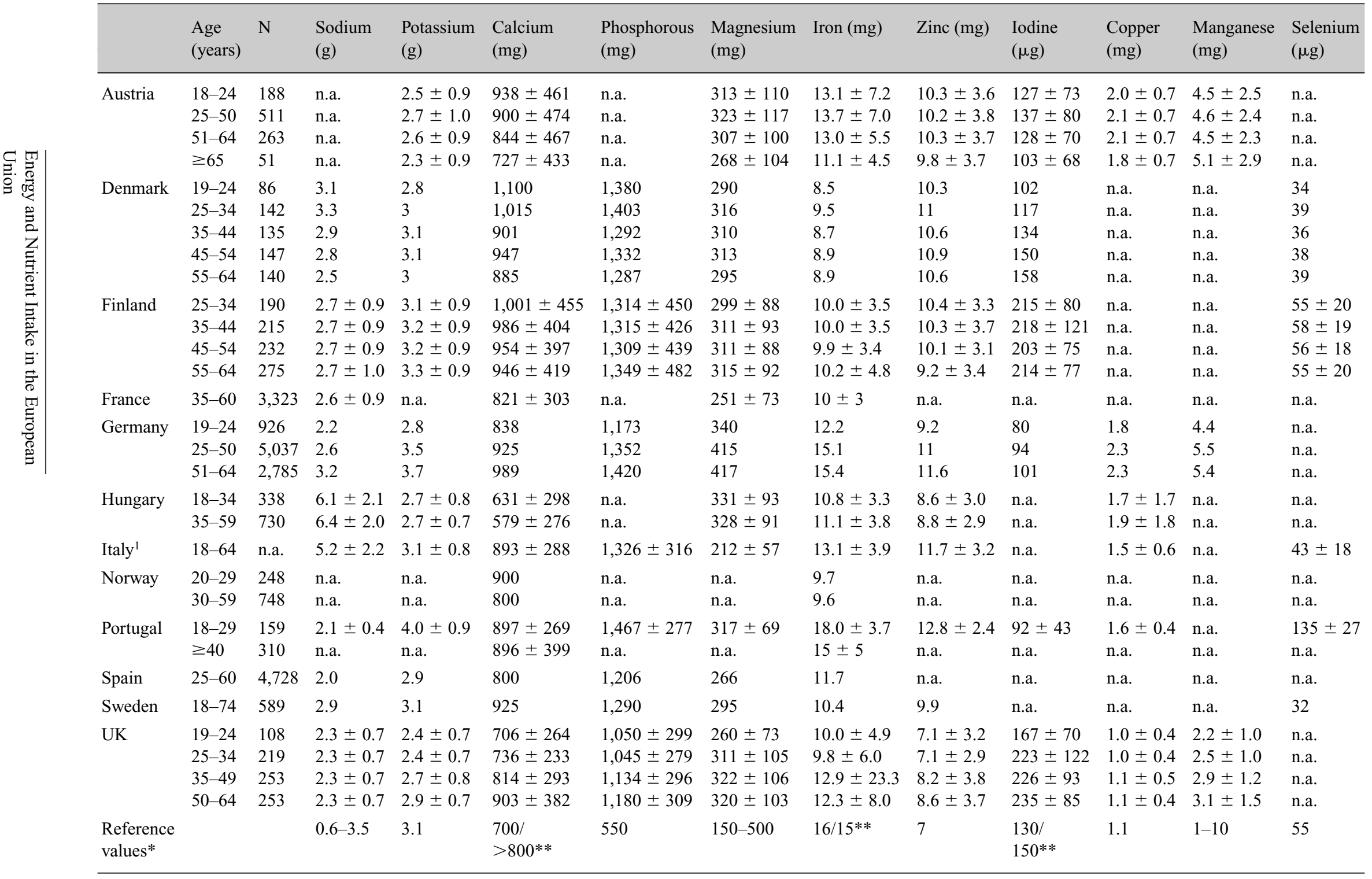

1 Men and women.

* SCF, 1993; ** Eurodiet, 2000; n.a. = not available. 
Portuguese women, the average intake in women of all age groups and countries was clearly below the guideline of $15 \mathrm{mg}$ /day [Eurodiet, 2000].

The average iodine intake was particularly high and clearly above the indicated requirement of $150 \mu \mathrm{g} /$ day [Eurodiet, 2000] in Finnish and UK adults. An insufficient average intake of iodine was observed in Austrian men older than 50 years and in Austrian women of all age groups, in Portuguese and German adults, as well as in some age groups of Danish women and men. The average supply of zinc was relatively good. There were only a few age groups in Finland and the UK which had an intake below the recommendation of the SCF (1993). The mean selenium intake was too low in Denmark, Italy and Sweden, but only five countries assessed this nutrient. The average supply of magnesium, copper and manganese can be regarded as sufficient.

\section{Energy and Nutrient Intake in European Elderly}

More than half of the participating countries had data of energy and nutrient intake in elderly (table 17). Here again, the age groups are not homogeneous, and also the methods used for the assessment of dietary intake data were different among the participating countries (table 17). Data from Belgian elderly as well as Hungarian elderly aged 70-75 years have to be interpreted with caution, as they are limited only to these population groups of the elderly and are more than 12 years old.

The SCF (1993) does not indicate specified recommendations for elderly. Thus, in this report, the intake data of European elderly is compared to the recommendations for adults.

\section{Energy and Macronutrients}

On average, the energy intake was lower in elderly than in adults of the same countries. The mean proportion of protein in total energy intake was within the recommended range of the WHO (2003) in elderly of most countries, or slightly above it (table 18). The highest average proportion was found in Spanish men and women, but also in Norwegian women it was relatively high. Like in European adults, the mean share of carbohydrates was low in European elderly as well. Only in Norwegian and Portuguese elderly and in Hungarian women aged $70-75$ years the average carbohydrate intake was higher than $50 \% \mathrm{E}$. In UK elderly it was on average $50 \% \mathrm{E}$ and higher as well, but it has to be considered that it is the percentage of food energy only. This means that considering the energy intake from alcohol,
Table 17. Method and period of dietary assessment in elderly of European countries

\begin{tabular}{llll}
\hline Country & Age group & Method & Year of survey \\
\hline Austria & $55-\geq 85$ years & 24-hour-recall & 2002 \\
Belgium & $70-75$ years & 24-hour-recall & 1988 \\
Denmark & $65-80$ years & $\begin{array}{l}\text { 7-day-record, personal } \\
\text { interview }\end{array}$ & 1995 \\
Germany & $\geq 65$ years & HBS & 1998 \\
Greece & $65-\geq 75$ & Semi- & $1994-1999$ \\
& & quantitative FFQ & (EPIC data \\
& & & collected at the \\
Hungary & $\geq 60$ years (m) & 3 & national level) \\
& $\geq 55$ years (f) & FFQ & $1992-1994$ \\
Italy & $70-75$ years & 7-day-record, personal & $1994-1996$ \\
Norway & 665 years & interview & 1988 \\
Portugal & $70-75$ years & FFQ & 1997 \\
Spain & $65-75$ & 24-hour-recall & $1990-1998$ \\
UK & $\geq 65$ & 4-day-weighed record & 1995 \\
\hline
\end{tabular}


Table 18. Intake of energy and macronutrients (mean \pm SD) in elderly of European countries (men and women)

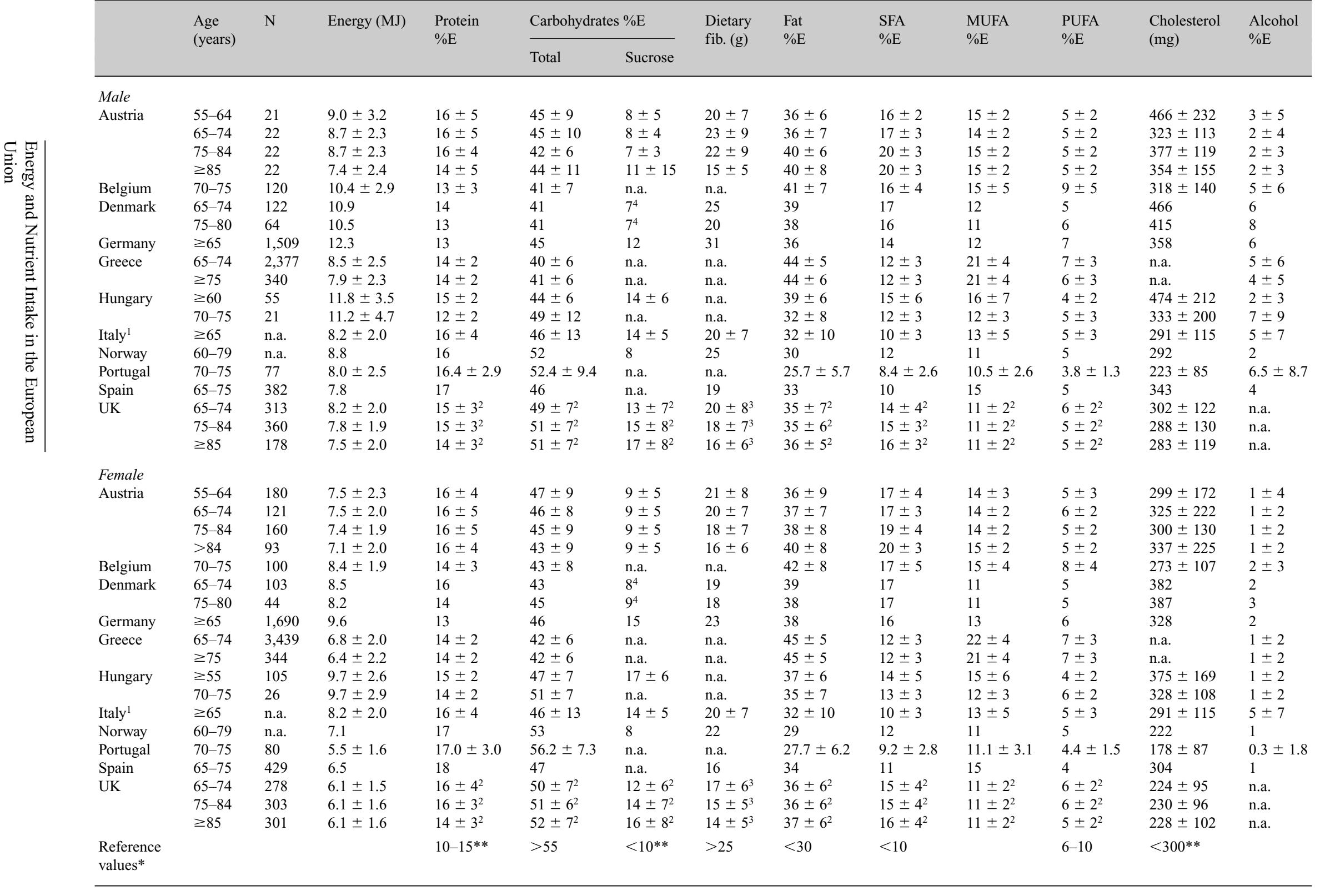

1 Men and women, ${ }^{2}$ \% of total food energy (excl. alcohol), ${ }^{3}$ Non-starchy polysaccharides, ${ }^{4}$ added sucrose.

* Eurodiet, 2000; ** WHO, 2003; n.a. = not available. 
this level would probably be lower. The recommended level of at least $55 \% \mathrm{E}$ [Eurodiet, 2000] was not reached by elderly of any country.

The proportion of this nutrient in total energy intake was particularly low in Belgian, and Danish elderly men, and in Greek elderly of both sexes. On average the carbohydrate intake was in elderly women higher than in elderly men. The mean sucrose intake in European elderly was generally below the upper level of $10 \% \mathrm{E}$ [WHO, 2003]. In German, Hungarian and UK elderly men and women it was however clearly above this recommended upper level. Especially in Hungarian elderly women it was very high with $17 \% \mathrm{E}$. The mean dietary fibre intake varied in elderly people among the participating countries. In Austrian men and women older than 84 years, as well as in Spanish elderly women it was very low. Only in German and Norwegian elderly men, as well as in Danish men aged 65-74 years, the recommendation of Eurodiet (2000) was reached.

As a consequence of the low intake of carbohydrates, the proportion of fat was rather high in European elderly. The highest intakes were found in Greek men and women, but also in Belgium, Austria, Denmark, Germany, and Hungary the proportion was considerable. The lowest average fat intake was observed in Norwegian elderly. Apart from Greece, countries with a high total fat intake had a high average intake of SFA as well. In Austrian elderly men older than 74 years and women older than 84 years it was $20 \% \mathrm{E}$, which was the 2 -fold of the recommended upper level Eurodiet (2000). In Spain, Italy, Greece and Norway the mean SFA intake was low compared to the other countries. The PUFA intake was in general too low in European elderly. The highest mean intake was found in Belgian elderly. In German and Greek elderly it was on average sufficient as well. Due to the generally high fat intake in European elderly, the mean cholesterol intake was high as well. Especially in men it was generally above the upper level of $300 \mathrm{mg} /$ day indicated by the WHO (2003). Also in Danish and Hungarian women, as well as in women of some other countries this upper level was exceeded. The lowest mean cholesterol intakes were found in Norway, Italy and the UK. Despite the high proportion of fat in total energy intake in Belgian elderly, the mean cholesterol intake was not as high as in most other countries, in women it was even below the recommended upper level.

The highest mean proportion of alcohol in total energy intake was found in Danish, German and Hungarian men, but also in Italian adults it was considerable.

\section{Vitamins}

According to table 19, the vitamin A intake in elderly people of the participating countries was on average above the population reference intake of the SCF (1993). Only in Hungarian elderly men and women aged 70-75 years the mean vitamin A intake was with 0.3 and $0.4 \mathrm{mg} /$ day, respectively, clearly below these recommendations.

The mean vitamin $\mathrm{D}$ intake was below the recommended intake of $10 \mu \mathrm{g} /$ day [Eurodiet, 2000] in elderly men and women of all countries. The highest mean intake was found in Norwegian men with $5.8 \mu \mathrm{g} /$ day, followed by Austrian men aged 55-74 years with 5.0-5.1 $\mu \mathrm{g} /$ day. For vitamin E intake the SCF does not give any absolute recommendations. In general, the average vitamin E intake was clearly lower in European elderly than in adults of the same countries, and it was higher in elderly men than in elderly women.

The thiamine intake was on average sufficient in the European population. Only in Hungarian men and women aged $70-75$ years, as well as in Italian elderly and Austrian elderly men older than 84 years the mean intake was below the recommended value. Apart from Hungary, the average riboflavin intake was above the population reference intake in elderly women of the participating countries. In men a low intake of riboflavin was more prevalent. A sufficient mean intake was only observed in Denmark, Germany and Norway. The mean niacin supply was good in European elderly. Only in Norwegian men it was below the population reference intake of the SCF (1993). A low vitamin $B_{6}$ intake was found in Austrian and Hungarian men. In all other countries it can on average be regarded as sufficient. The mean food folate intake was among women and men of all countries below the recommended level of $400 \mu \mathrm{g} /$ day [Eurodiet, 2000]. The supply of cobalamin and ascorbic acid in European elderly can on average be regarded as sufficient.

\section{Minerals}

The mean estimated sodium intake was relatively high in European elderly, especially in men. The highest intake was found in Hungarian elderly men ( $7.4 \mathrm{~g} /$ day) and women $(6.2 \mathrm{~g} /$ day $)$, followed by Italian elderly (5.4 g/day) (table 20). The mean supply of potassium was not sufficient in elderly of most of the participating countries. Only in Danish men and in German men and women the average intake of this nutrient can be regarded as sufficient. The mean calcium intake was 
Table 19. Vitamin intake (mean $\pm \mathrm{SD}$ ) in elderly of European countries (men and women)

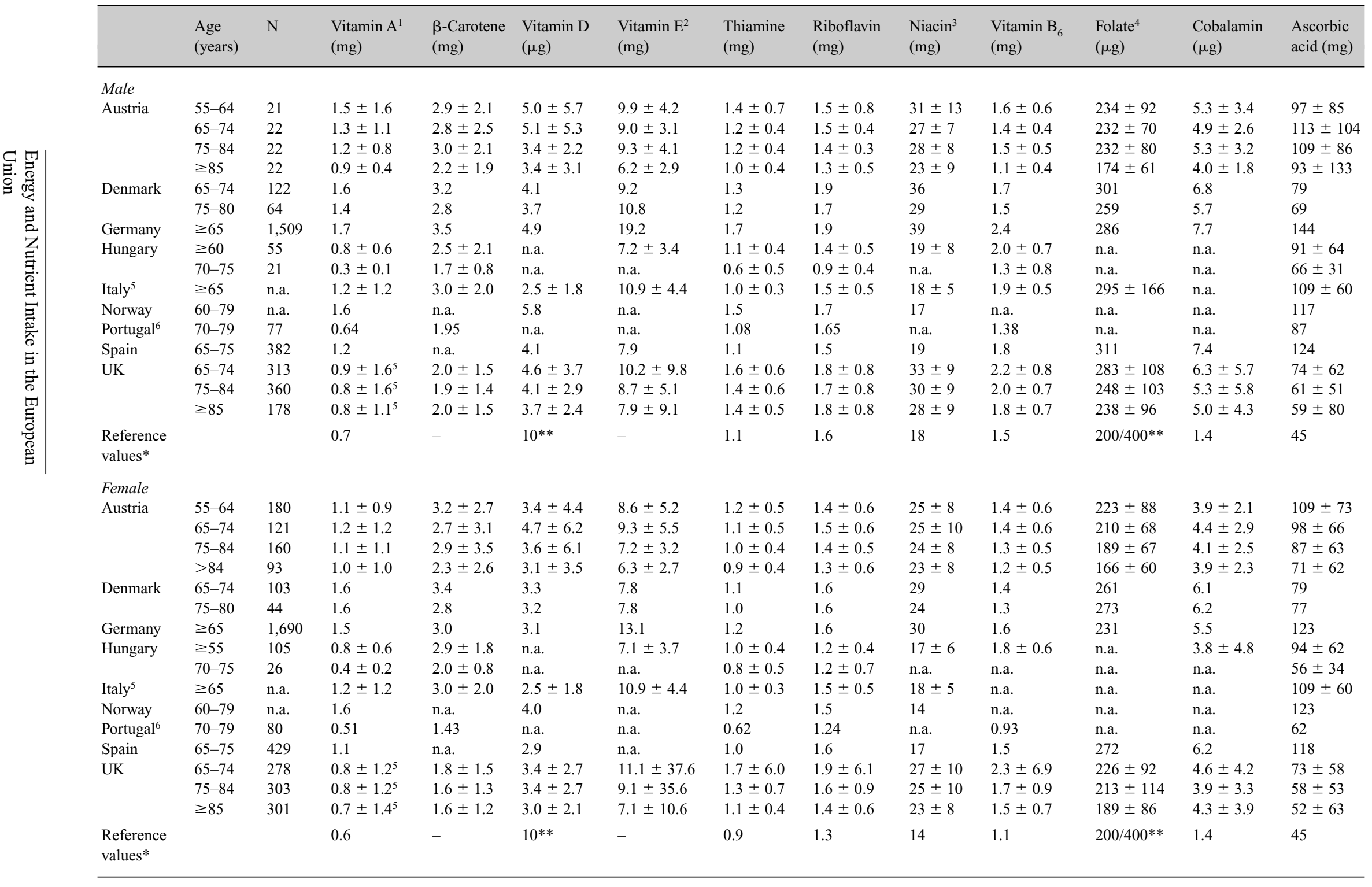

1 Retinol equivalent $(=1 \mathrm{mg}$ retinol $=6 \mathrm{mg}$ all-trans- $\beta$-carotene $=12 \mathrm{mg}$ other carotenoids $),{ }^{2}$ RRR- $\alpha$-Tocopherol equivalent $(=\mathrm{mg} \quad \alpha$-tocopherol $+\mathrm{mg} \quad \beta$-tocopherol $\times 0.5+\mathrm{mg} \gamma$ tocopherol $\times 0.25+\mathrm{mg} \alpha$-tocotrienol $\times 0.33),{ }^{3}$ Niacin equivalent $(=1 \mathrm{mg}$ niacin $=60 \mathrm{mg}$ tryptophan $),{ }^{4}$ Folate equivalent $(=1 \mu \mathrm{g}$ food folate $=0.5 \mu \mathrm{g}$ folic acid $(\mathrm{PGA})=0.6 \mu \mathrm{g}$ folic acid taken with meals), ${ }^{5}$ Preformend retinol; ${ }^{6}$ values correspond to the median (P50).

* SCF, 1993; ** Eurodiet, 2000; n.a. = not available. 
Table 20. Mineral intake (mean $\pm \mathrm{SD}$ ) in elderly of European countries (men and women)

\begin{tabular}{|c|c|c|c|c|c|c|c|c|c|c|c|c|c|}
\hline & $\begin{array}{l}\text { Age } \\
\text { (years) }\end{array}$ & $\mathrm{N}$ & $\begin{array}{l}\text { Sodium } \\
\text { (g) }\end{array}$ & $\begin{array}{l}\text { Potassium } \\
(\mathrm{g})\end{array}$ & $\begin{array}{l}\text { Calcium } \\
(\mathrm{mg})\end{array}$ & $\begin{array}{l}\text { Phosphorous } \\
\text { (mg) }\end{array}$ & $\begin{array}{l}\text { Magnesium } \\
(\mathrm{mg})\end{array}$ & Iron (mg) & Zinc (mg) & $\begin{array}{l}\text { Iodine } \\
(\mu \mathrm{g})\end{array}$ & $\begin{array}{l}\text { Copper } \\
(\mathrm{mg})\end{array}$ & $\begin{array}{l}\text { Manganese } \\
(\mathrm{mg})\end{array}$ & $\begin{array}{l}\text { Selenium } \\
(\mu \mathrm{g})\end{array}$ \\
\hline \multicolumn{14}{|l|}{ Male } \\
\hline \multirow{6}{*}{ Denmark } & $55-64$ & 21 & n.a. & $2.6 \pm 1.2$ & $635 \pm 402$ & n.a. & $311 \pm 152$ & $14.2 \pm 5.4$ & $12.7 \pm 7.1$ & $123 \pm 52$ & n.a. & n.a. & n.a. \\
\hline & $65-74$ & 22 & n.a. & $2.8 \pm 1.0$ & $959 \pm 400$ & n.a. & $341 \pm 98$ & $14.7 \pm 4.3$ & $12.5 \pm 3.9$ & $136 \pm 54$ & n.a. & n.a. & n.a. \\
\hline & $75-84$ & 22 & n.a. & $2.5 \pm 0.8$ & $695 \pm 266$ & n.a. & $281 \pm 85$ & $14.4 \pm 6.0$ & $11.8 \pm 3.3$ & $119 \pm 23$ & n.a. & n.a. & n.a. \\
\hline & $\geq 85$ & 22 & n.a. & $1.9 \pm 1.9$ & $642 \pm 642$ & n.a. & $233 \pm 84$ & $10.0 \pm 2.9$ & $9.1 \pm 3.3$ & $102 \pm 34$ & n.a. & n.a. & n.a. \\
\hline & $65-74$ & 122 & 3.6 & 3.8 & 954 & 1,641 & 380 & 11.9 & 13.5 & 143 & n.a. & n.a. & 49 \\
\hline & $75-80$ & 64 & 3.4 & 3.3 & 822 & 1,404 & 334 & 9.7 & 11.1 & 101 & n.a. & n.a. & 41 \\
\hline Germany & $\geq 65$ & 1,509 & 4.3 & 4.2 & 1,031 & 1,657 & 474 & 17.8 & 13.5 & 127 & 2.7 & 6.0 & n.a. \\
\hline \multirow[t]{2}{*}{ Hungary } & $\geq 60$ & 55 & $7.4 \pm 1.9$ & $2.9 \pm 0.8$ & $699 \pm 365$ & n.a. & $381 \pm 112$ & $12.4 \pm 3.8$ & n.a. & n.a. & n.a. & n.a. & n.a. \\
\hline & $70-75$ & 21 & n.a. & n.a. & $638 \pm 220$ & n.a. & & $9.7 \pm 2.8$ & n.a. & n.a. & n.a. & n.a. & n.a. \\
\hline Italy $^{1}$ & $\geq 65$ & n.a. & $5.4 \pm 2.9$ & $3.0 \pm 0.8$ & $845 \pm 263$ & $1,242 \pm 295$ & $199 \pm 56$ & $12.6 \pm 4.0$ & $10.7 \pm 3.1$ & n.a. & n.a. & n.a. & n.a. \\
\hline Norway & $60-79$ & n.a. & n.a. & n.a. & 900 & n.a. & n.a. & 11.0 & n.a. & n.a. & n.a. & n.a. & n.a. \\
\hline Portuga $^{2}$ & $70-79$ & 77 & n.a. & n.a. & 766 & n.a. & n.a. & 12.8 & n.a. & n.a. & n.a. & n.a. & n.a. \\
\hline Spain & $65-75$ & 382 & 1.7 & 3.0 & 714 & 1,218 & 295 & 12.5 & n.a. & n.a. & n.a. & n.a. & n.a. \\
\hline \multirow[t]{3}{*}{ UK } & $65-74$ & 313 & $2.8 \pm 0.9$ & $2.8 \pm 0.8$ & $856 \pm 290$ & $1,261 \pm 340$ & $258 \pm 79$ & $11.5 \pm 6.6$ & $9.0 \pm 2.7$ & $193 \pm 82$ & $1.1 \pm 0.7$ & n.a. & n.a. \\
\hline & $75-84$ & 360 & $2.7 \pm 0.9$ & $2.5 \pm 0.7$ & $840 \pm 302$ & $1,179 \pm 331$ & $233 \pm 77$ & $10.6 \pm 3.9$ & $8.4 \pm 2.8$ & $185 \pm 80$ & $1.0 \pm 0.6$ & n.a. & n.a. \\
\hline & $\geq 85$ & 178 & $2.6 \pm 0.9$ & $2.3 \pm 0.6$ & $847 \pm 285$ & $1,134 \pm 308$ & $214 \pm 69$ & $10.1 \pm 4.1$ & $8.0 \pm 2.6$ & $177 \pm 73$ & $0.9 \pm 0.4$ & n.a. & n.a. \\
\hline \multicolumn{3}{|l|}{$\begin{array}{l}\text { Reference } \\
\text { values* }\end{array}$} & $0.6-3.5$ & 3.1 & $\begin{array}{l}700 / \\
>800 * *\end{array}$ & 550 & $150-500$ & 9 & 9.5 & $\begin{array}{l}130 / \\
150^{* *}\end{array}$ & 1.1 & $1-10$ & 55 \\
\hline \multicolumn{14}{|l|}{ Female } \\
\hline \multirow[t]{4}{*}{ Austria } & $55-64$ & 180 & n.a. & $2.6 \pm 0.9$ & $831 \pm 409$ & n.a. & $286 \pm 98$ & $12.6 \pm 6.6$ & $10.4 \pm 3.3$ & $130 \pm 56$ & n.a. & n.a. & n.a. \\
\hline & $65-74$ & 121 & n.a. & $2.6 \pm 0.9$ & $799 \pm 402$ & n.a. & $288 \pm 101$ & $12.3 \pm 5.0$ & $10.3 \pm 3.7$ & $135 \pm 55$ & n.a. & n.a. & n.a. \\
\hline & $75-84$ & 160 & n.a. & $2.3 \pm 0.8$ & $780 \pm 361$ & n.a. & $271 \pm 110$ & $11.0 \pm 4.1$ & $10.1 \pm 3.1$ & $122 \pm 56$ & n.a. & n.a. & n.a. \\
\hline & $>84$ & 93 & n.a. & $2.1 \pm 0.8$ & $649 \pm 351$ & n.a. & $235 \pm 86$ & $11.1 \pm 7.3$ & $9.2 \pm 3.4$ & $111 \pm 42$ & n.a. & n.a. & n.a. \\
\hline \multirow[t]{2}{*}{ Denmark } & $65-74$ & 103 & 2.8 & 3.2 & 912 & 1,366 & 307 & 9.0 & 11.2 & 111 & n.a. & n.a. & 41 \\
\hline & $75-80$ & 44 & 2.5 & 2.8 & 864 & 1,264 & 276 & 8.5 & 9.8 & 115 & n.a. & n.a. & 39 \\
\hline Germany & $\geq 65$ & 1,690 & 3.0 & 3.5 & 886 & 1,276 & 377 & 13.4 & 10.1 & 91 & 2.1 & 4.6 & \\
\hline \multirow[t]{2}{*}{ Hungary } & $\geq 55$ & 105 & $6.2 \pm 1.8$ & $2.7 \pm 0.8$ & $613 \pm 264$ & n.a. & $328 \pm 96$ & $10.8 \pm 3.3$ & n.a. & n.a. & $1.4 \pm 1.3$ & n.a. & n.a. \\
\hline & $70-75$ & 26 & n.a. & n.a. & $838 \pm 527$ & n.a. & n.a. & $9.8 \pm 5.1$ & n.a. & n.a. & n.a. & n.a. & n.a. \\
\hline Italy $^{1}$ & $\geq 65$ & n.a. & $5.4 \pm 2.9$ & $3.0 \pm 0.8$ & $845 \pm 263$ & $1,242 \pm 295$ & $199 \pm 56$ & $12.6 \pm 4.0$ & $10.7 \pm 3.1$ & n.a. & $1.3 \pm 0.5$ & n.a. & $39 \pm 17$ \\
\hline Norway & $60-79$ & n.a. & n.a. & n.a. & 800 & n.a. & n.a. & 9.0 & n.a. & n.a. & n.a. & n.a. & n.a. \\
\hline Portugal $^{2}$ & $70-79$ & 80 & n.a. & n.a. & 548 & n.a. & n.a. & 7.0 & n.a. & n.a. & n.a. & n.a. & n.a. \\
\hline Spain & $65-75$ & 429 & 1.5 & 2.9 & 759 & 1,133 & 250 & 10.1 & n.a. & n.a. & n.a. & n.a. & n.a. \\
\hline \multirow[t]{3}{*}{ UK } & $65-74$ & 278 & $2.1 \pm 0.7$ & $2.3 \pm 0.6$ & $720 \pm 251$ & $1,032 \pm 275$ & $208 \pm 61$ & $9.4 \pm 3.5$ & $7.2 \pm 2.2$ & $154 \pm 62$ & $0.9 \pm 0.5$ & n.a. & n.a. \\
\hline & $75-84$ & 303 & $2.1 \pm 0.6$ & $2.1 \pm 0.5$ & $729 \pm 270$ & $983 \pm 268$ & $188 \pm 60$ & $8.4 \pm 3.0$ & $7.0 \pm 2.8$ & $151 \pm 63$ & $0.9 \pm 0.6$ & n.a. & n.a. \\
\hline & $\geq 85$ & 301 & $2.0 \pm 0.7$ & $2.0 \pm 0.6$ & $718 \pm 273$ & $940 \pm 278$ & $178 \pm 55$ & $7.9 \pm 2.9$ & $6.5 \pm 2.3$ & $149 \pm 67$ & $0.8 \pm 0.5$ & n.a. & n.a. \\
\hline $\begin{array}{l}\text { Reference } \\
\text { values* }\end{array}$ & & & $0.6-3.5$ & 3.1 & $\begin{array}{l}700 / \\
>800^{* *}\end{array}$ & 550 & $150-500$ & 9 & 7 & $\begin{array}{l}130 / \\
150^{* *}\end{array}$ & 1.1 & $1-10$ & 55 \\
\hline
\end{tabular}

1 Male and female, ${ }^{2}$ values correspond to the median (P50).

* $\quad$ SCF, 1993; n.a. $=$ not available. 
below the recommended level of at least $800 \mathrm{mg} /$ day [Eurodiet, 2000] in Austrian men and women of nearly all age groups, in Hungarian and Spanish men and women, and in female elderly of the UK. Also the supply of iron was on average relatively good. As postmenopausal women do not have higher requirements than men, the average intake was compared to the recommendation of the SCF (1993) for male adults. According to this recommendation, the mean intake was too low in Danish women aged 75-80 years, and in UK women aged 75 years and older. A low zinc intake was observed in Austrian men older than 84 years, in women of the UK older than 84 years, and in elderly UK men of all age groups.

The iodine intake was assessed in Austria, Denmark, Germany and the UK. Apart from the UK, the average iodine intake was below the recommended level of $150 \mu \mathrm{g} /$ day [Eurodiet, 2000] in both elderly men and women of these countries. The supply of magnesium, copper and manganese in European countries can on average be regarded as sufficient. Only in UK elderly the intake of copper was below the recommended level. 